\title{
21. SILICOFLAGELLATE BIOSTRATIGRAPHY AND PALEOECOLOGY IN THE EASTERN EQUATORIAL PACIFIC, DEEP SEA DRILLING PROJECT LEG 54
}

\author{
David Bukry, United States Geological Survey, Scripps Institution of Oceanography, La Jolla, California
}

\section{INTRODUCTION}

Leg 54 of the Deep Sea Drilling Project was designed to study young oceanic igneous rocks and associated geochemical phenomena in the tropical eastern Pacific Ocean. Several upper Pliocene to Quaternary biogenous sediment sections were cored incidentally to the primary igneous coring program. Two of the sites (Sites 424 and 425 ) are in the southern part of the Panama Basin on the flanks of the Galapagos spreading center. The others are clustered on the western flank of the East Pacific Rise at the junction of the Siqueiros fracture zone (Figure 1). The sediment sections of the Siqueiros area, Sites 419 through 423 and 427 through 429 , contain sufficient silicoflagellates to recognize several previously described zones (Figure 2). Dissolution thinning of specimens is common and the uppermost Quaternary Dictyocha aculeata aculeata Zone is missing in all the Siqueiros sites but Site 427. One new silicoflagellate, Dictyocha aculeata subaculeata Bukry, is described from Leg 54.

The mid-Quaternary Mesocena quadrangula Zone is well represented in the Siqueiros and Galapagos areas. At Site 422, the regional acme of Mesocena quadrangula is found above and below an intercalated basaltic rock unit. The negative magnetization reported for the unit and the $M$. quadrangula abundance signify it is not part of the Jaramillo polarity event, but is probably only slightly older (Hays et al., 1969; Saito and Burckle, 1977) - about 1 m.y.

At Site 425 near the Galapagos Islands, silicoflagellates are especially abundant, diverse, and well preserved. This site was clearly affected by the high fertility of the Peru Current, since the assemblages are similar to those cored at DSDP Sites 157 and 321 to the south. The basal Quaternary samples contain sparse Dictyocha perlaevis ornata, a typical upper Pliocene and lowest Quaternary taxon in the Atlantic. This species may prove useful in biogeographic studies between the Pacific and Atlantic oceans, but was not recognized at the Siqueiros sites because of dissolution.

The occurrence of silicoflagellates at Sites 419, 420, $422,425,427$, and 428 is shown in six separate figures which are interspersed through the text. These figures also record the number of opal phytoliths and Thalassiosira leptopus elliptica (diatom) encountered during the silicoflagellate counts. Opal phytoliths are skeletal elements from terrestrial grasses that are an aeolian addition to the sediment (Bukry, this volume). Thalassiosira leptopus elliptica is a large distinctive form which was reported to occur only in the Quaternary of the tropical eastern Pacific (Bukry and Foster, 1973). That relation is supported by its near absence from the Pliocene at the four sites of Leg 54 where Pliocene was recovered, dissolution withstanding. See Barron (this volume) for taxonomic and stratigraphic discussion of this subspecies. Presence, absence, and blooms of the giant diatom Ethmodiscus rex are also indicated on the figures.

\section{ZONATION}

The four silicoflagellate zones used to characterize Leg 54 assemblages include three widespread zones identified from the Atlantic Ocean and one regional zone or subzone for the tropical eastern Pacific Ocean. The Dictyocha stapedia stapedia Zone, Mesocena quadrangula Zone, and Dictyocha aculeata aculeata Zone are widely applicable and have been described in Bukry (1979a). The Dictyocha perlaevis delicata Zone (or Subzone) was defined as a local zone from a re-study of Site 157 (Bukry, 1976a). Its presence at Site 425 in the Galapagos area and Sites 419,420 , and 428 in the Siqueiros area confirms its local utility in the equatorial eastern Pacific near Sites 157 and 425 and extends its range over $8^{\circ}$ of latitude to the northwest to include the northern part of the tropical eastern Pacific.

Because the Dictyocha stapedia stapedia Zone and Dictyocha perlaevis delicata Zone or Subzone were both defined immediately below the cosmopolitan low- to mid-latitude Mesocena quadrangula Zone, a shortened (emended) D. stapedia stapedia Zone could be employed in the eastern Pacific to accommodate the $D$. perlaevis delicata Zone. Alternatively, the $D$. perlaevis delicata biostratigraphic unit could be designated an upper subzone of the more cosmopolitan $D$. stapedia stapedia Zone. Whichever usage prevails, the first $D$. perlaevis delicata s. str. is used to identify the base of the $D$. perlaevis delicata biostratigraphic unit. The last consistent $D$. perlaevis delicata and the beginning of the $M$. quadrangula acme are used to mark the top of the zone. These criteria overlap at one site (Site 420), where the abrupt diminution of $D$. perlaevis delicata is used to designate the top of the subzone. The regional $D$. perlaevis delicata disappearance is considered more isochronous than the beginning of the $M$. quadrangula acme, since identification is less equivocal. 


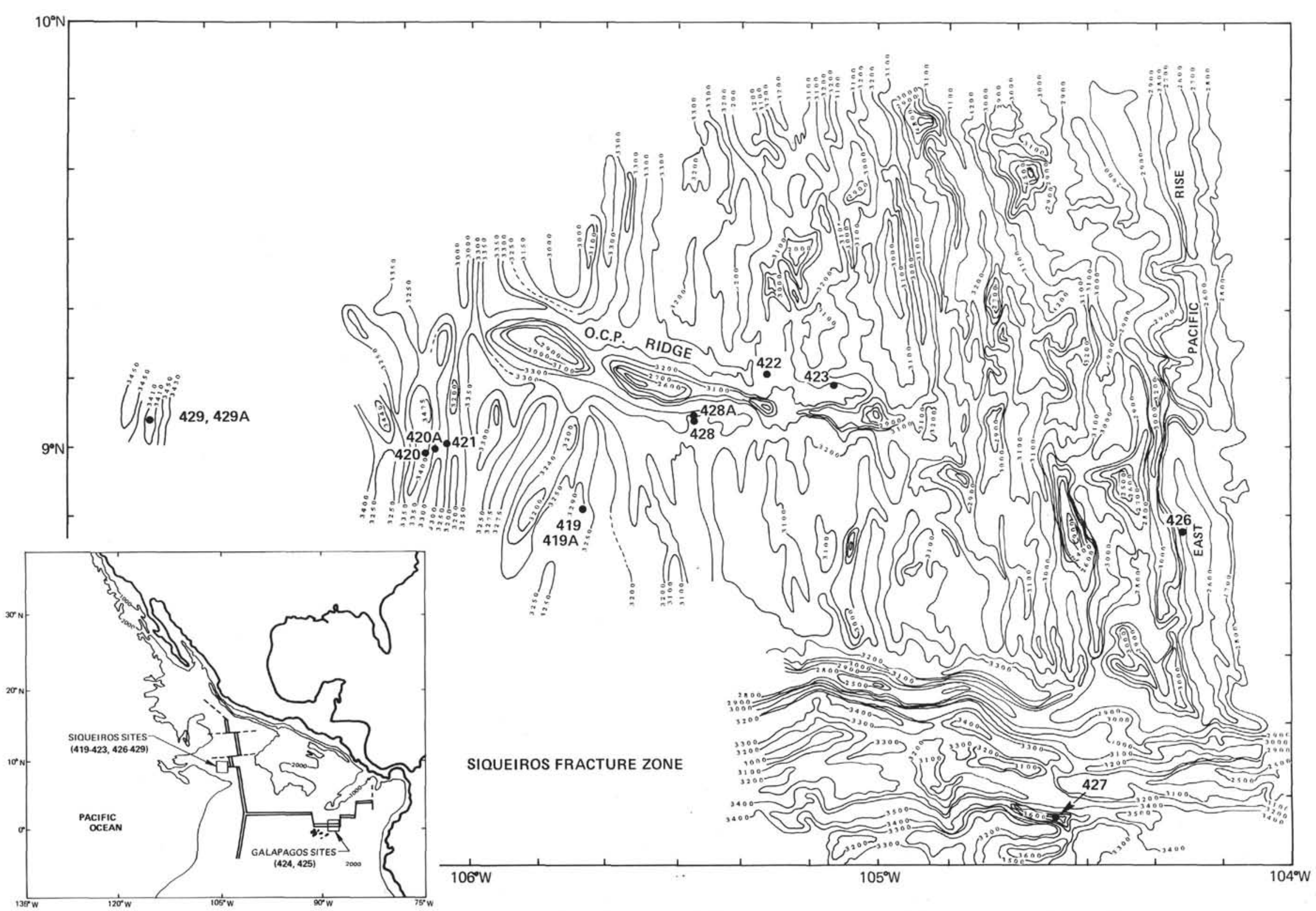

Figure 1. Location of Sites 419 through 423 and 426 through 429 for DSDP Leg 54; bathymetry in meters. Inset: Location of Sites 424 and 425 on the flanks of the Galapagos Rise Crest; bathymetry in fathoms. 


\begin{tabular}{|c|c|c|c|c|c|c|c|}
\hline Age & Zone & 419 & 420 & 422 & 425 & 427 & 428 \\
\hline \multirow{4}{*}{ 总 } & $\begin{array}{c}\text { Dictyocha } \\
\text { aculeata } \\
\text { aculeata }\end{array}$ & & & & $\begin{array}{c}1-1 \\
\text { to } \\
3-6\end{array}$ & $\begin{array}{c}3-2 \\
\text { to } \\
4-2\end{array}$ & \\
\hline & $\begin{array}{l}\text { Mesocena } \\
\quad \text { quadrangula }\end{array}$ & $\begin{array}{c}4-1 \\
\text { to } \\
4-5\end{array}$ & $\begin{array}{l}4-5 \\
\text { to } \\
7-1\end{array}$ & $\begin{array}{c}4-2 \\
\text { to } \\
8-3\end{array}$ & $\begin{array}{c}4-1 \\
\text { to } \\
5-1\end{array}$ & $\begin{array}{c}7-1 \\
\text { to } \\
8-5\end{array}$ & $\begin{array}{c}2-3 \\
\text { to } \\
3-3 \\
\end{array}$ \\
\hline & $\begin{array}{c}\text { Dictyocha } \\
\text { perlaevis } \\
\text { delicata }\end{array}$ & $5-2$ & $\begin{array}{c}7-4 \\
\text { to } \\
10-5\end{array}$ & & $\begin{array}{c}5-2 \\
\text { to } \\
5-4\end{array}$ & & $\begin{array}{l}3-5 \\
\text { to } \\
5-1\end{array}$ \\
\hline & $\begin{array}{c}\text { Dictyocha } \\
\text { stapedia } \\
\text { stapedia }\end{array}$ & & $\begin{array}{c}11-1 \\
\text { to } \\
13-1\end{array}$ & & $\begin{array}{c}6-1 \\
\text { to } \\
6-2\end{array}$ & & \\
\hline
\end{tabular}

Figure 2. Summary of silicoflagellate zonal assignments for Leg 54. The numbers assigned to zonal intervals are core and section numbers of samples examined.

\section{SITE SUMMARIES}

\section{Site 419}

$\left(08^{\circ} 55.96^{\prime} \mathrm{N}, 1^{\circ} 5^{\circ} 41.17^{\prime} \mathrm{W}\right.$, depth $\left.3274 \mathrm{~m}\right)$

Dissolution has strongly affected the Quaternary silicoflagellates at Site 419. At least half of the specimens of the dominant species, Mesocena quadrangula and Dictyocha stapedia stapedia, in Sample 419-4-4, 132$134 \mathrm{~cm}(25 \mathrm{~m})$ are solution thinned and ghostlike in appearance. The samples from Cores 1 through 3 are barren of silicoflagellates. That interval is also the upper interval of the Quaternary, where the warm-water coccolith Gephyrocapsa oceanica becomes abundant throughout the region. Thus, the lack of silicoflagellates could be primary, resulting from a major change in fertility, or secondary, resulting from accelerated dissolution in carbonate-rich sediment (Mikkelsen, 1978) or a combination of both. The occurrence pattern of silicoflagellates is highly variable, as two samples, $50 \mathrm{~cm}$ apart, in a single section (Section 2) of Core 5 have abundant and trace numbers (Figure 3).

A distinctive lower Quaternary species, Dictyocha lingii occurs in Sample 419-4-1, 124-126 cm (21 m) and in only two other samples from Leg 54 , Sections 422-4-2 and 425-5-3. The occurrences at Sites 419 and 422 are in the Mesocena quadrangula Zone, its typical range (Dumitricá, 1973a). The occurrence at Site 425 is slightly lower in the Dictyocha perlaevis delicata Zone, but all three occurrences are within the coccolith Emiliania ovata Subzone.

\section{Site 420}

\section{$\left(09^{\circ} 00.10^{\prime} \mathrm{N}, 106^{\circ} 06.77^{\prime} \mathrm{W}\right.$, depth $\left.3381 \mathrm{~m}\right)$}

Although Site 420 is the most stratigraphically comprehensive and best preserved site from the standpoint of calcareous plankton, the upper Pliocene and Quaternary silicoflagellate assemblages are sparse or poorly preserved except in Cores 7 and 8. The major shift in silicoflagellate assemblages occurs between Sections 7-1 and 7-4, where prominent Dictyocha perlaevis s. ampl. of the lower Quaternary are displaced by the acme of
Mesocena quadrangula (Figure 4). This event might represent slight cooling, but there is no significant change in the abundance of temperature-sensitive Distephanus speculum speculum, so changes in nutrient levels may be involved.

The top of the silicoflagellate-bearing section is in Core 4, which, like Site 419, is also the level where the regional upper Quaternary abundance of the warmwater coccolith Gephyrocapsa oceanica begins.

It should be pointed out that Mesocena quadrangula occurs in Pliocene and basal Quaternary samples of Site 420 below its zonal acme level. This helps to confirm its older distribution as reported at Site 157 (Bukry and Foster, 1973; Saito and Burckle, 1977). The first Quaternary occurrence of $M$. quadrangula may be illusionary, because low counts of a silicoflagellate assemblage may not detect its presence until the level of its acme is encountered. The mid-Quaternary acme of $M$. quadrangula has been widely applied for biostratigraphy, following its popularization by Hays et al. (1969) in the tropical eastern Pacific. Saito and Burckle (1977) report that the extinction of $M$. quadrangula can be correlated as occurring between the Jaramillo polarity event and the end of the Matuyama polarity epoch ( 0.70 to 0.89 m.y. B.P.) in the North and equatorial Pacific; this would support the isochronous disappearance reported by Ling (1970). They also identify this extinction at Isotopic Stage 22 of Shackleton and Opdyke (1976), a time of Northern Hemisphere glaciation. They therefore conclude a climatic linkage with its extinction. Unfortunately, dissolution tops at several sites and mixing at Site 425 preclude correlation by this means at Leg 54 sites.

\section{Site 422 \\ $\left(09^{\circ} 10.59^{\prime} \mathrm{N}, 105^{\circ} 16.27^{\prime} \mathrm{W}\right.$, depth $\left.3247 \mathrm{~m}\right)$}

The assemblages of silicoflagellates at Site 422 are dominated by Mesocena quadrangula (Figure 5) and are all strongly dissolved. The specimens from Cores 4 and 5 above a 4-meter basaltic rock layer are solution thinned and ghostlike in appearance. Specimens from below the rock layer, in Core 8, are only slightly better. Regardless of preservation, it is clear that the silicoflagellate assemblages above and below the basalt layer are part of the Mesocena quadrangula acme interval, estimated to have its peak 0.85 to $0.95 \mathrm{~m} . \mathrm{y}$. B.P. (Jousé and Mukhina, 1973), but to range from 0.79 to 1.3 m.y. B.P. (Burckle, 1977). Therefore, the negatively magnetized basalt layer which occurs within sediment above a positively magnetized Olduvai polarity event basement is probably slightly older than the Jaramillo event ( 0.89 to 0.95 m.y. B.P., LaBrecque et al., 1977). Assuming the Hays et al. (1969) correlation is correct, an age of approximately $1 \mathrm{~m}$.y. could be assigned to the basalt layer.

\section{Site 424, Hole 424B}

$\left(00^{\circ} 35.82^{\prime} \mathrm{N}, 8^{\circ} 07.82^{\prime} \mathrm{W}\right.$, depth $\left.2699 \mathrm{~m}\right)$

An assemblage of 19 silicoflagellates from Sample 424B-2-3, 120-122 cm (8 m) contains 10 Dictyocha perlaevis perlaevis, $4 \mathrm{D}$. stapedia aspinosa, $2 \mathrm{D}$. sp., $1 \mathrm{D}$. 


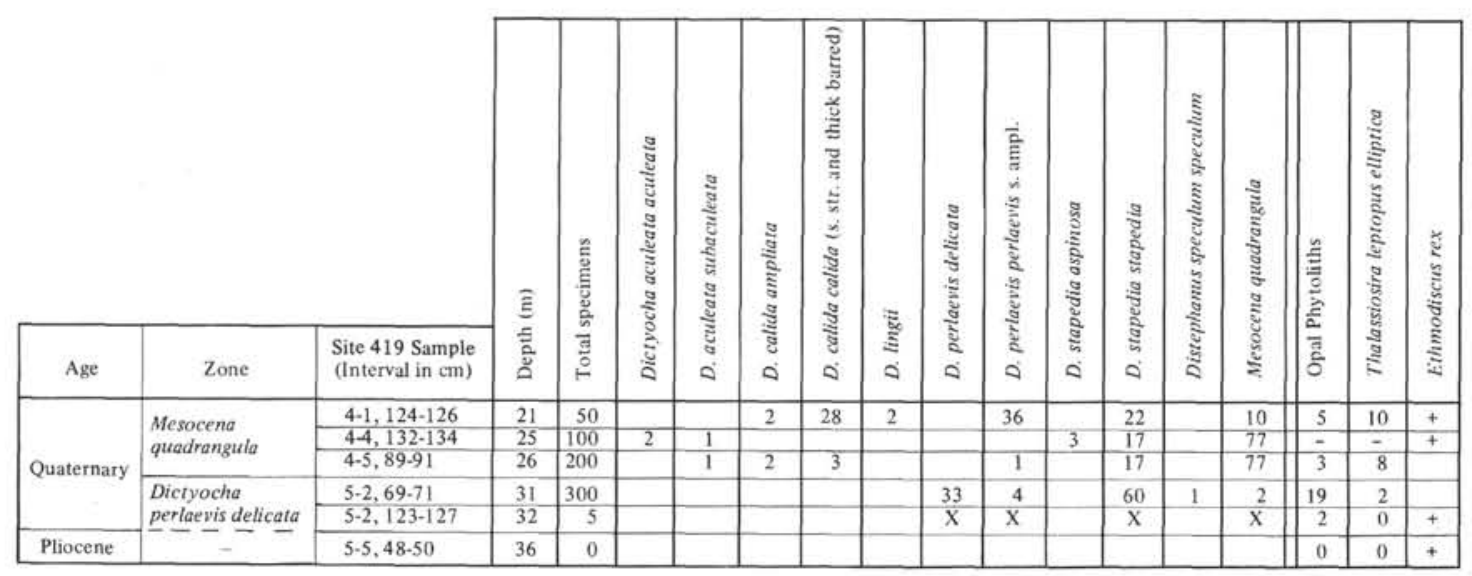

Figure 3. Quaternary silicoflagellates recorded as percentages from Cores 4 and 5 at Site 419. Samples from Cores 1 through 3 are barren. Numbers of opal phytoliths and the diatom Thalassiosira leptopus elliptica intersected during traverses for silicoflagellates are recorded. Dash $=$ not recorded $. \mathrm{x}=$ present. The occurrence of the distinctive diatom Ethmodiscus rex (see Mikkelsen, 1977) is also recorded. $\bullet=$ abundant.$+=$ present. Sample 419-5-5, 48-50 $\mathrm{cm}$ is assigned to the Pliocene on the basis of coccolith stratigraphy.

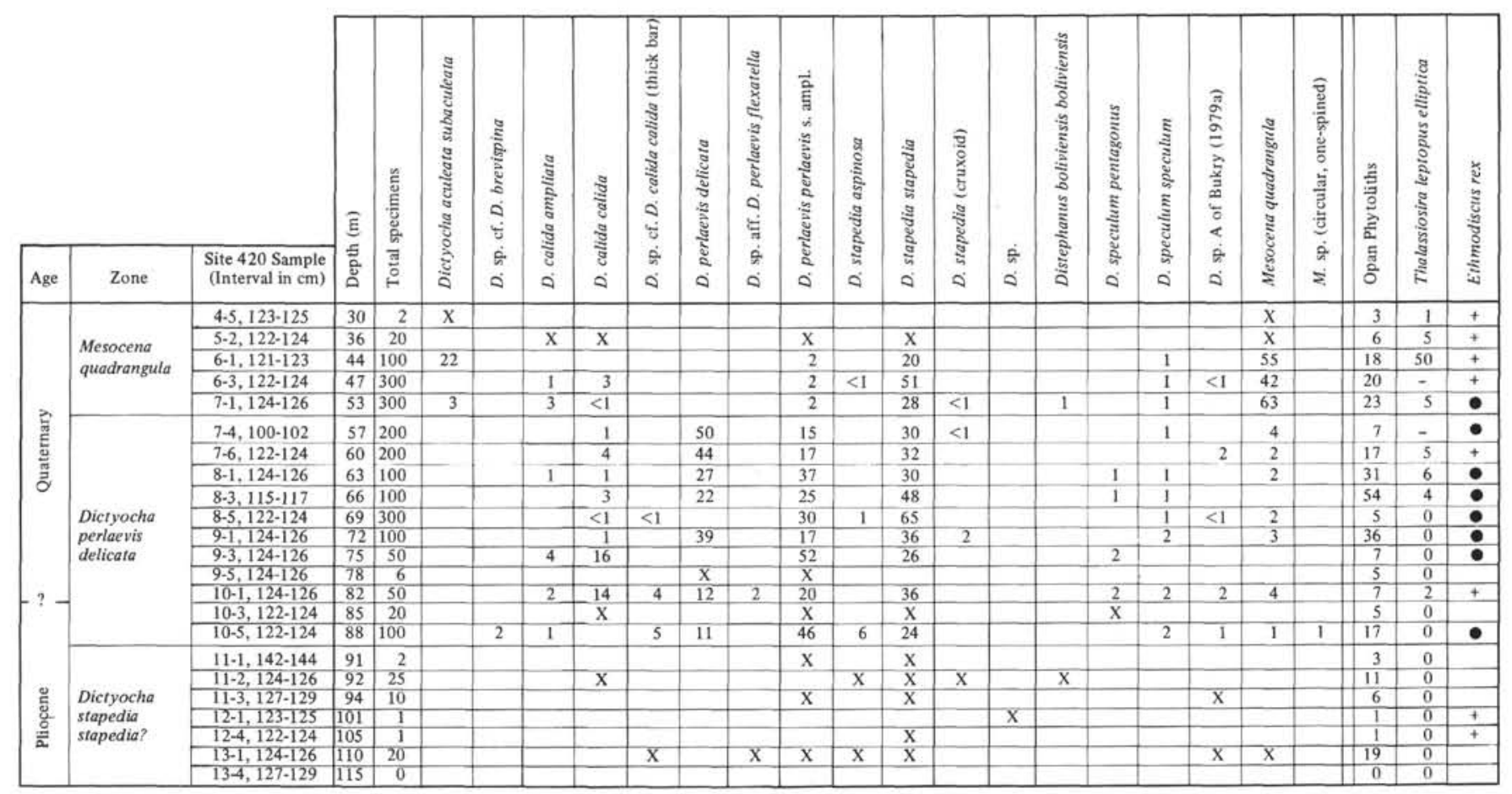

Figure 4. Quaternary and Pliocene silicoflagellates recorded as percentages or presence (where counts are too sparse) from Cores 4 through 13 at Site 420 . Numbers of opal phytoliths and the diatom Thalassiosira leptopus elliptica intersected during traverses for silicoflagellates are recorded. Dash $=$ not recorded. $\mathrm{x}=$ present. The occurrence of the distinctive diatom Ethmodiscus rex (see Mikkelsen, 1977) is also recorded. $\bullet=$ abundant. $+=$ present .

sp. (naviculopsoid), 1 Distephanus speculum speculum, and 1 Mesocena quadrangula. This is a poorly diagnostic assemblage which can be assigned to the Quaternary based on assemblages at nearby Site 425 .

\section{Site $\mathbf{4 2 5}$ \\ $\left(01^{\circ} 23.68^{\prime} \mathrm{N}, 8^{\circ} 04.22^{\prime} \mathrm{W}\right.$, depth $\left.2850 \mathrm{~m}\right)$}

Silicoflagellate assemblages of Site 425 are the most abundant, diverse, and best preserved of Leg 54. The transition from the last common Distephanus speculum speculum to the first common Mesocena quadrangula between Cores 5 and 6 (Figure 6) matches the same transition at Site 321 under a more southerly part of the Peru Current (Bukry, 1976a). In general, Site 425 is comparable to the Peru Current sites of Legs 16 and 34 rather than to the Siqueiros sites of Leg 54 .

The basal assemblages of Core 6 contain Dictyocha perlaevis ornata and $D$. perlaevis flexatella which pro- 


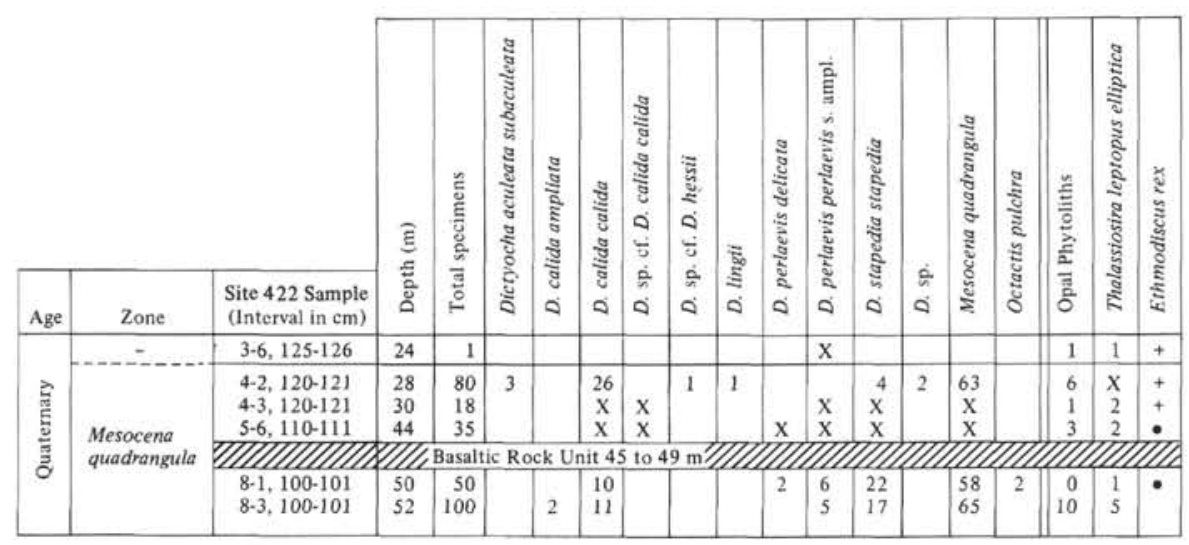

Figure 5. Quaternary silicoflagellates recorded as percentages from Cores 3 through 5, and 8 at Site 422; Cores 6 and 7 contain a basaltic rock unit. Samples from Cores 1 and 2 are barren. Numbers of opal phytoliths and the diatom Thalassiosira leptopus elliptica intersected during traverses for silicoflagellates are recorded. Dash $=$ not recorded $\mathrm{x}=$ present. The occurrence of the distinctive diatom Ethmodiscus rex (see Mikkelsen, 1977) is also recorded.

vide correlation of upper Pliocene and basal Quaternary assemblages between the North and South Atlantic (Bukry, 1977a, b; 1979b). Poor preservation of this level at the Siqueiros sites prevents their correlation there.

\section{Site 427 \\ $\left(08^{\circ} 06.79^{\prime} \mathrm{N}, 1^{\circ} 36.35^{\prime} \mathrm{W}\right.$, depth $\left.3834 \mathrm{~m}\right)$}

The only Dictyocha aculeata Zone silicoflagellates preserved in the Siqueiros sites occur in Cores 3 and 4 at Site 427. These low-diversity, solution-thinned assemblages with sparse $D$. aculeata aculeata (Figure 7) occur between barren horizons - Samples 2-2, 70-71 cm (4 $\mathrm{m})$ and 6-4, 74-76 $\mathrm{cm}(66 \mathrm{~m})$. These assemblages are dominated by Dictyocha species, indicating warm-water conditions.

The Mesocena quadrangula Zone of Cores 7 and 8 is dominated by $M$. quadrangula and probably represents the upper part of the zone, approximately 0.8 to 1.05 m.y. B.P.

\section{Site 428 \\ $\left(09^{\circ} 02.77^{\prime} \mathrm{N}, 105^{\circ} 26.14^{\prime} \mathrm{W}\right.$, depth $\left.3295 \mathrm{~m}\right)$}

A dramatic shift from Dictyocha perlaevis delicata dominated assemblages to Mesocena quadrangula dominated ones occurs within the lower part of Core 3 (Figure 8). The upper D. perlaevis delicata Zone or Subzone sediment has fewer foraminifers (less carbonate) and more sponge spicules than the following $M$. quadrangula Zone interval. The relation in abundances between these two silicoflagellates at Sites 419 and 420 in the Siqueiros area is the same, but carbonate shows the opposite change. Carbonate content decreases in an upward direction across the zone boundary there, as evidenced by reduced coccolith abundances (see Initial Core Descriptions, DSDP Leg 54). Samples from above and below the boundary at Site 428 contain, respective- ly, sparse and abundant Ethmodiscus rex (diatom), whereas at Site 420 , samples that bracket the boundary both contain abundant $E$. rex. The change in dominance from $D$. perlaevis delicata to $M$. quadrangula is a useful regional biostratigraphic guide, because it occurs consistently in the same interval relative to events in other microfossil groups. It occurs in the lower Emiliania ovata Subzone of coccoliths, the Nitzschia reinholdii (b) Zone (below the Rhizosolenia matuyamai Horizon) of diatoms, and in the Anthocyrtidium angulare Zone of radiolarians at Sites 419,420 , and 428 .

\section{SILICOFLAGELLATE TAXONOMY}

Genus DICTYOCHA Ehrenberg, 1837

\section{Dictyocha aculeata aculeata (Lemmermann) (Plate 1, Figures 1-3)}

not Dictyocha aculeata Ehrenberg, 1840, p. 148.

Dictyocha epiodon Ehrenberg, Ehrenberg, 1854 (in part), pl. 25B (IV), fig. 10.

not Dictyocha aculeata Ehr., Stöhr, 1880, p. 120, pl. 7, fig. 7a, b.

Dictyocha fibula var. aculeata Lemmermann, 1901, p. 261, pl. 11, fig. 1,2 .

Dictyocha fibula var. aculeata Lemm., Gemeinhardt, 1930, p. 55, fig. $43 a, b$.

Dictyocha fibula var. aculeata Lemm., Frenguelli, 1935, pl. 13, fig. 1-9.

not Dictyocha speculum var. aculeata (Ehrenberg) Frenguelli, 1941, p. 94, pl. 1, fig. 6.

Dictyocha fibula Ehr. var. aculeata Lemmermann, Tsumura, 1963, p. 54 , pl. 10 , fig. 9 ; pl. 23, fig. 6 .

Dictyocha fibula "var." aculeata Lemmermann, Ling, 1970, p. 91, pl. 18, fig. 11-13.

Dictyocha fibula Ehrenberg s. 1., Martini, 1971 (in part), p. 1696, pl. 1 , fig. 5 .

Dictyocha fibula var. aculeata Lemmermann, Tampieri, 1972, p. 378, pl. 34 , fig. 1,2 ; pl. 35 , fig. 1 .

Dictyocha aculeata (Lemmermann), Dumitrică, 1973a, p. 907, pl. 9, fig. 5-10. 


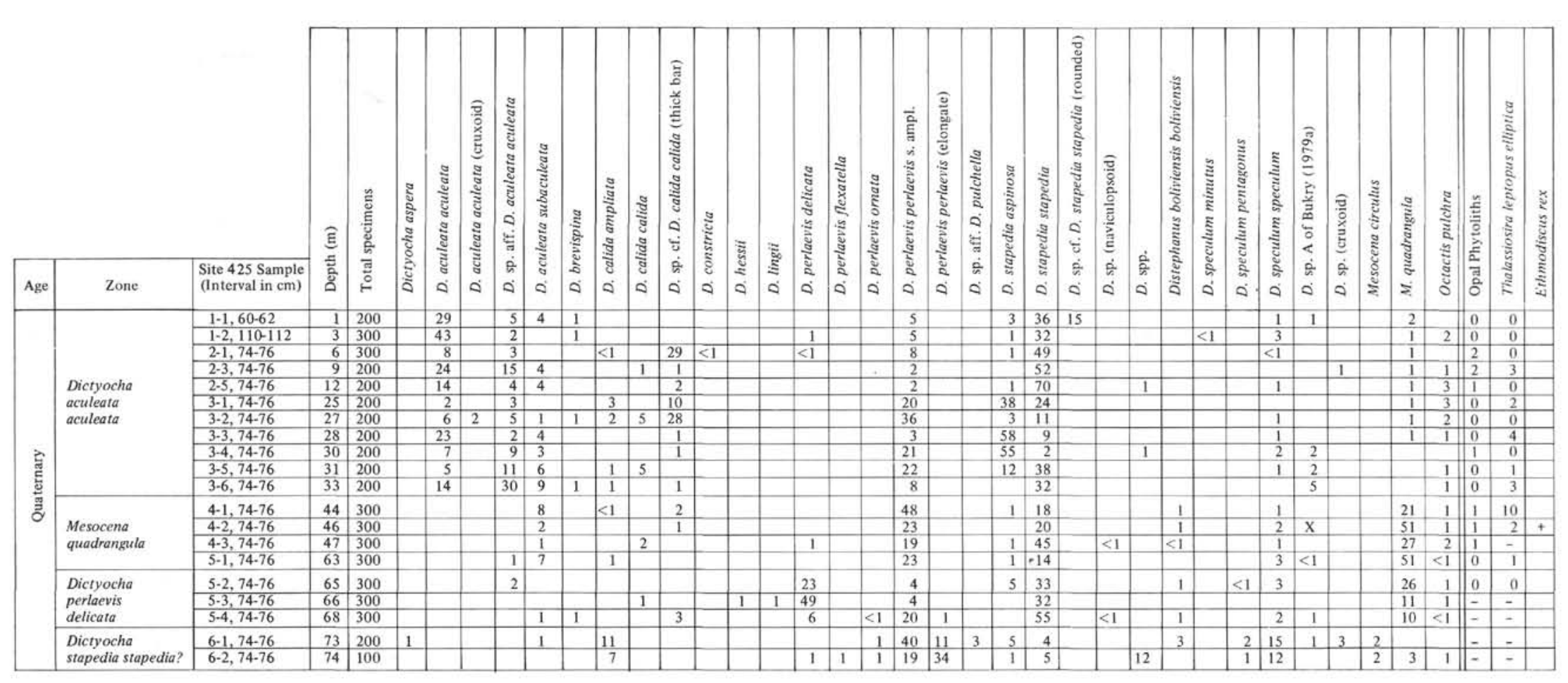

Figure 6. Quaternary silicoflagellates recorded as percentages from Cores 1 through 6 at Site 425 . Number of opal phytoliths and the diatom Thalassiosira leptopus elliptica intersected during traverses for silicoflagellates are recorded. Dash $=$ not recorded. $\mathrm{x}=$ present. The occurrence of the distinctive diatom Ethmodiscus rex (see Mikkelsen, 1977) is also recorded. $\bullet=$ abundant.$+=$ present. 


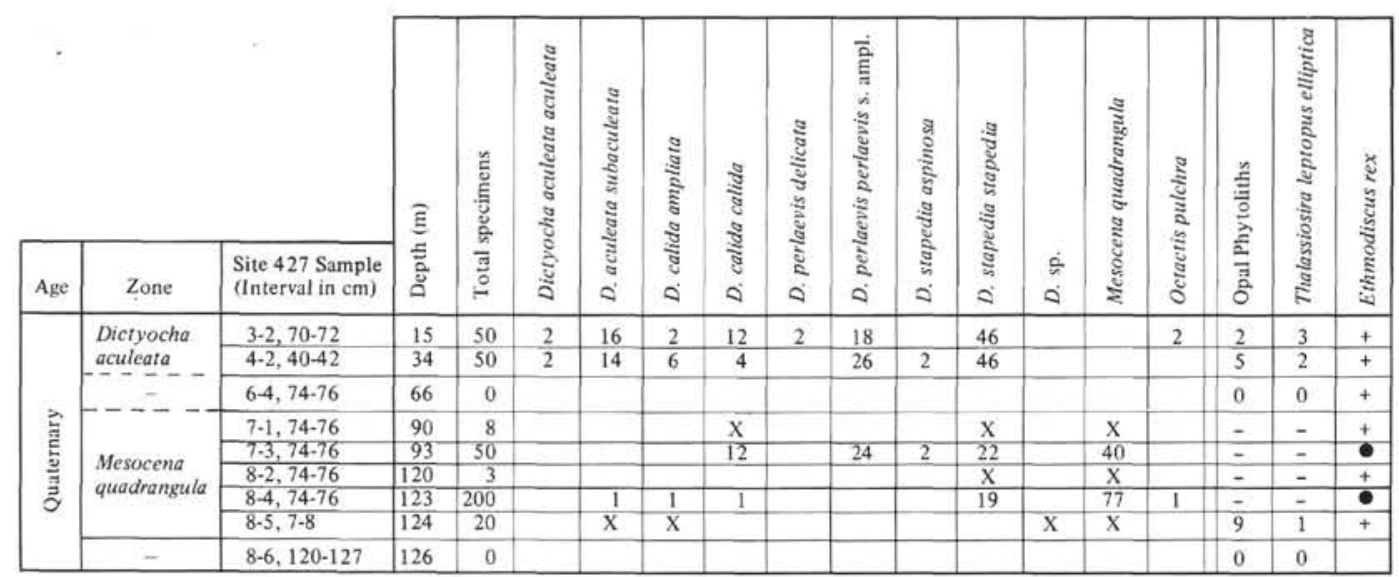

Figure 7. Quaternary silicoflagellates recorded as percentages from Cores 3 through 8 at Site 427. Numbers of opal phytoliths and the diatom Thalassiosira leptopus elliptica intersected during traverses for silicoflagellates were recorded for some samples. Dash $=$ not recorded. $\mathrm{x}=$ present. The occurrence of the distinctive diatom Ethmodiscus rex (see Mikkelsen, 1977) is also recorded $. \bullet=$ abundant.$+=$ present.

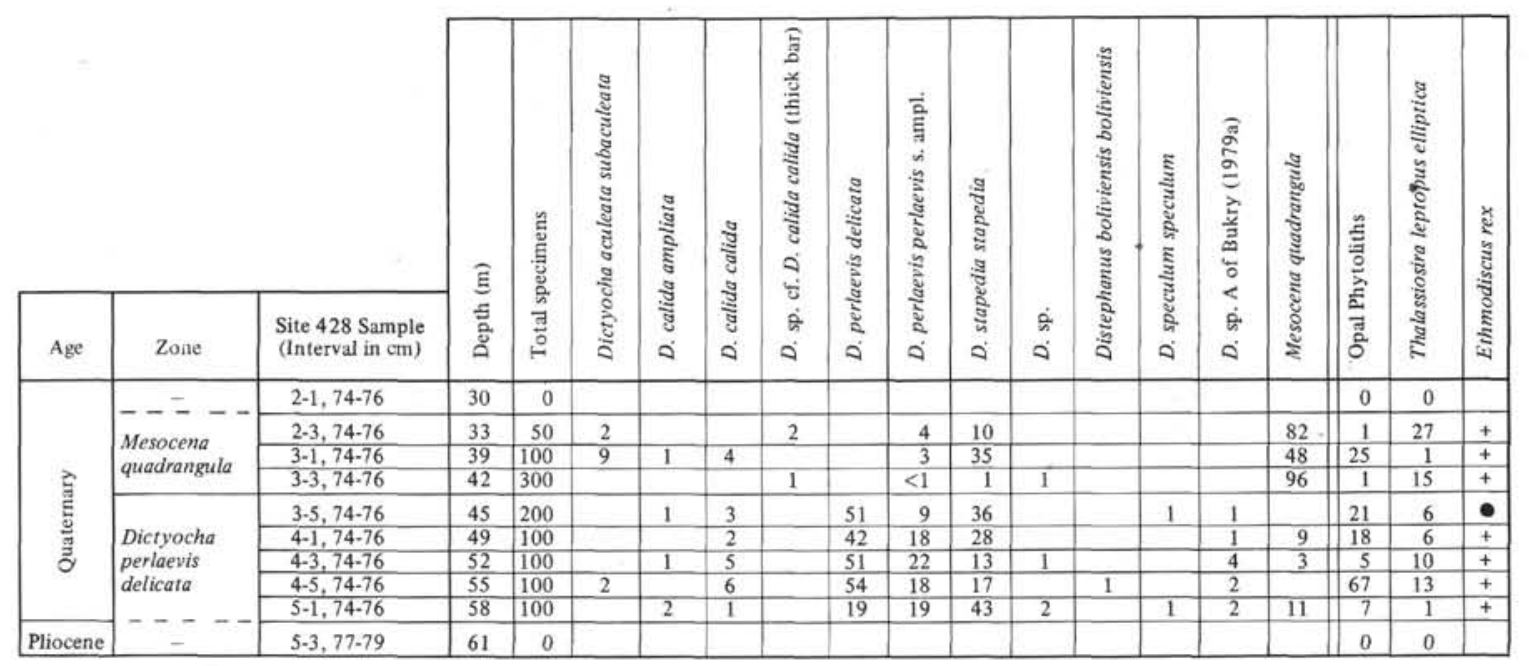

Figure 8. Quaternary silicoflagellates recorded as percentages from Cores 2 through 5 at Site 428. A sample from Core 1 is barren, but contains sparse opal phytoliths. The number of opal phytoliths and the diatom Thalassiosira leptopus elliptica intersected during traverses for silicoflagellates are recorded. The occurrence of the distinctive diatom Ethmodiscus rex (see Mikkelsen, 1977) is also recorded. $\bullet=$ abundant. $+=$ present. Sample 428-5-3, 77-79 cm is assigned to the Pliocene on the basis of coccolith stratigraphy.

Dictyocha epiodon Ehrenberg, Bukry and Foster, 1973, p. 826, pl. 2, fig. 7,8 .

Dictyocha aculeata (Lemmermann), Dúmitricà, 1973b, p. 849, pl. 4, fig. 9-11.

Dictyocha aculeata (Lemmermann), Perch-Nielsen, 1975, p. 686, pl. 5 , fig. 3,4 .

Dictyocha fibula var. aculeata Lemmermann, Ling, 1975, p. 768, pl. 1, fig. 7, 8 .

Dictyocha epiodon Ehrenberg, Poelchau, 1976, p. 170, pl. 1, fig. e, f; pl. 4 , fig. 2 d.

Dictyocha fibula var. aculeata Ehrenberg, Ling 1976, pl. 29, fig. 2.

Dictyocha aculeata (Lemmermann), Martini, 1976 (in part), p. 442, pl. 1, fig. 2, (not pl. 2, fig. 3a, b).

Dictyocha mandrai Ling, nom. nov., 1977, p. 209, pl. 1, fig. 13, 14. Dictyocha aculeata (Lemmermann), Bukry, 1977a, p. 921.

Remarks: The distinctive Quaternary silicoflagellate skeleton, having four definite peripheral pikes on the basal ring between the axial spines, was first illustrated by Ehrenberg as Dictyocha epiodon, and later as Dictyocha fibula var. aculeata by Lemmermann. The latter name has achieved majority usage in this century, even though prior to Locker's (1974) type selection, D. epiodon could have been given priority (Bukry, 1977a). Owing to this long-term usage in the literature, a suggested substitute name (Dictyocha mandrai Ling, 1977) is not used here and it is recommended that the name Dictyocha aculeata (Lemmermann) be conserved.

Historically, Ehrenberg (1840) used the name Dictyocha aculeata first, but applied it to a hexagonal, apical-ringed silicoflagellate, before the genus Distephanus (apical-ringed silicoflagellates) had been named. Ehrenberg's taxa was transferred to Distephanus by Haeckel (1887), because it was very similar to the type species $D$. rotundus and differed only by the prominence of its apical or basal pikes.

I agree with Ling (1977, p. 210) that Distephanus aculeatus (Ehrenberg) is virtually conspecific with Distephanus speculum (Ehrenberg) which, in turn, is virtually conspecific with Distephanus 
rotundus, the type species of genus Distephanus (see Stöhr, 1880, pl. 7). However, because Distephanus aculeatus (Ehrenberg) was transferred into genus Distephanus by Haeckel (1887) prior to the naming of Dictyocha fibula var. aculeata Lemmermann (1901), the name aculeata was not preoccupied in genus Dictyocha and may be considered the first available use of the name for purposes of priority at that rank. This relationship is supported by ICBN Art. 60 (Lanjouw et al., 1966). Also, by ICBN Art. 14, Note 5, if Dictyocha aculeata (Lemmermann) is considered a conserved name because of its long consistent usage, then it may be conserved against any earlier homonym. Although the application may be indirect, ICZN Art. 59(C)i (Stoll et al., 1964) indicates that if the senior of two homonyms (in the same genus) is no longer considered congeneric and is transferred to another genus, then the former junior homonym takes precedence in the genus.

In short, Ehrenberg's aculeatus should be legitimate in genus Distephanus and Lemmermann's aculeata should be legitimate in genus Dictyocha. A substitute name would be necessary only if both were placed into the same genus.

Dictyoch a aculeata aculeata can be distinguished from $D$, aculeate subaculeata by the four peripheral pikes on the basal ring and by the exposed location of all four inwardly directed basal pikes. Other criteria are discussed under $D$. aculeata subaculeata. Short-spined, large specimens of $D$. aculeata aculeata that lack one or two peripheral pikes but are otherwise comparable are tabulated as $D$. sp. aff. D. aculeata aculeata (Plate 1, Figures 4-7).

\section{Dictyocha aculeata subaculeata $\mathrm{n}$. subsp.}

(Plate 1, Figures 8-17)

?Dictyocha messanensis Haeckel, Dumitrică, 1973a (in part), p. 907, pl. 8 , fig. 11-13.

Dictyocha sp. cf. D. aculeata Lemmermann (rounded), Bukry, 1979a, p. 991 , pl. 1, fig. 5, 6?, 7-9.

Dictyocha sp. cf. D. aculeata Lemmermann, Bukry, 1979b, p. 569, pl. 1 , fig. 3,4 .

Description: Dictyocha aculeata subaculeata has a moderate to long bar which may or may not have a spire. The bar is slightly to moderately canted from the major axis. The four axial spines of the ring are moderate to long and the major axis spines, typically, are clearly longer than the minor axis spines, up to $2: 1$. The ring is basically rhomb-shaped with slightly rounded corners. The sides are slightly bowed out between the spines, sometimes forming a slight angle. Strut junctions are offset from the symmetry of the ring axes, and, of the four prominent basal pikes, two or three are widely offset from the junctions.

Remarks: Dictyocha aculeata subaculeata is often common in lower Quaternary assemblages. It appears to be the source of upper Quaternary $D$. aculeata aculeata and is distinguished from the latter by: (1) the absence of a set of four peripheral pikes on the interspine ring length; (2) the proximity of one or two basal pikes to the strut junctions - all four basal pikes are offset in D. aculeata aculeata; (3) the greater relative length of the major axis spines $-D$. aculeata aculeata populations are more nearly equant; and (4) the generally greater length of the spines relative to the inner diameter across the ring. It is distinguished from $D$. messanensis by its offset strut-ring junctions and inequant, shorter spines, and from $D$. subarctios by longer, inequant spines, the dominance of the major-axis spines, longer bar, and incompletely offset set of basal pikes.

Occurrence: Dictyocha aculeata subaculeata is a widespread subspecies that has been tabulated in the North Atlantic from the MidAtlantic Ridge (Site 412) to northwest Africa (Site 397) and in the North Pacific from Hess Rise (Site 310) to the Galapagos (Site 425). The illustrations by Dumitrica (1973a) are from Site 128 in the Mediterranean Sea. It ranges through most of the Quaternary at these mid- to low-latitude sites, but is most common in the lower or middle Quaternary.

Size: Maximum internal diameter 20 to $30 \mathrm{~mm}$.

Holotype: USNM 258919 (Plate 1, Figure 8).

Isotypes: USNM 258920 to 258928 .

Type locality: Equatorial eastern Pacific Ocean, Sample 425-4-2, $74-76 \mathrm{~cm}(46 \mathrm{~m})$.

\section{Dictyocha aspera (Lemmermann)}

(Plate 2, Figure 1)

Dictyocha fibula var. aspera Lemmermann, 1901, p. 260, pl. 10, fig. $27,28$.

\section{Dictyocha brevispina (Lemmermann)}

(Plate 2, Figure 2)

Dictyocha fibula var. brevispina Lemmermann, 1901, p. 260.

Dictyocha fibula var. aspera f. rhombica Schulz, 1928, p. 253, fig. 37.

\section{Dictyocha calida ampliata Bukry}

(Plate 2, Figure 6-8)

Dictyocha calida ampliata Bukry, 1979a, p. 982, pl. 2, fig. 1, $2,9$. Dictyocha calida ampliata Bukry, 1979b, p. 560, pl. 1, fig. 5, 6.

\section{Dictyocha calida calida Poelchau}

(Plate 2, Figure 3)

Dictyocha calida Poelchau, 1976, p. 169, pl. 1, fig. c, d; pl. 3, fig. a-f. Dictyocha calida calida Poelchau, Bukry, 1979b, p. 560, pl. 1., fig. 7.

Remarks: Many specimens of Dictyocha calida s. ampl. from Leg 54 resemble the type suite (Poelchau, 1976) very closely, except for having a thicker bar that matches the thickness of the struts and ring, instead of being thinner. Although this distinction may or may not be useful or even consistently reproducible, an attempt to establish the abundance of such forms was made by tabulating them as $D$. sp. cf. D. calida calida (thick bar). See Figures $4,6,8$, and Plate 2, Figures 4 and 5 .

\section{Dictyocha constricta (Schulz)}

Dictyocha fibula fa. constricta Schulz, 1928, p. 253, fig. 35a, b. Dictyocha constricta (Schulz) Bukry, 1979a, p. 983.

\section{Dictyocha hessii Bukry}

(Plate 3, Figures 1-4)

Dictyocha hessii Bukry, 1978a, p. 642.

Dictyocha hessii Bukry, Bukry, 1979b, p. 560, pl. 1, fig. 8-12.

\section{Dictyocha lingii Dumitricà}

(Plate 3, Figures 5-7)

Dictyocha lingi Dumitricà, 1973a, p. 906, pl. 8, fig. 1-7. Dictyocha lingii Dumitricá, Bukry, 1979a, p. 983, pl. 2, fig. 5-8.

\section{Dictyocha pentagona (Schulz)}

Dictyocha fibula var. pentagona Schulz, 1928, p. 255, fig. 41a, b. Dictyocha pentagona (Schulz), Bukry, 1976b, p. 894.

\section{Dictyocha perlaevis delicata Bukry}

(Plate 3, Figures 8-12)

Dictyocha perlaevis delicata Bukry, 1976a, p. 724, pl. 1, fig. 5-10.

\section{Dictyocha perlaevis flexatella Bukry}

Dictyocha perlaevis flexatella Bukry, 1979a, p. 984, pl. 3, fig. 1-3. Dictyocha perlaevis flexatella Bukry, Bukry, 1979b, p. 561, pl. 2, fig. 7-10.

\section{Dictyocha perlaevis ornata Bukry}

(Plate 4, Figure 1, 2)

Dictyocha perlaevis ornata Bukry, 1977a, p. 922, pl. 1, fig. 1-6. Dictyocha perlaevis ornata Bukry, Bukry, 1978a, p. 644, pl. 1, fig. 7, 8.

Dictyocha perlaevis ornata Bukry, Bukry, 1979b, p. 561, pl. 2, fig. 11-14. 
Dictyocha perlaevis perlaevis Frenguelli

(Plate 4, Figures 3-9; Plate 5, Figures 1-3)

Dictyocha perlaevis Frenguelli, 1951, p. 279, fig. 4b, c.

Dictyocha perlaevis perlaevis Frenguelli, Bukry, 1979a, p. 984, pl. 3, fig. 6-11.

Remarks: Dictyocha perlaevis perlaevis s. ampl. includes small numbers of pentagonal, crinkled, and arrowhead variations in the tabulated counts. Medium and large specimens are undifferentiated also. Medium specimens approach $D$. calida calida in form, but can be distinguished by greater ring scalloping, and longer and thicker bar with concomitant disparity of portal size along minor and major axes.

A distinctive local population, Dictyocha perlaevis perlaevis (elongate), in the basal Quaternary at Galapagos Site 425, is medium sized and has a much shorter minor axis than typical $D$. perlaevis perlaevis. The elongate population is separately tabulated and illustrated (Plate 4, Figures 10-13).

\section{Dictyocha pulchella Bukry}

Dictyocha pulchella Bukry, 1975a, p. 687, fig. 1-3.

Dictyocha pulchella Bukry, Bukry, 1979a, p. 984, pl. 4, fig. 1, 2.

\section{Dictyocha stapedia aspinosa Bukry}

(Plate 5, Figures 4-7)

Dictyocha stapedia aspinosa Bukry, 1976a, p. 724, pl. 2, fig. 6-9.

Dictyocha stapedia Haeckel var. aspinosa Bukry, Stradner and Bachmann, 1978 (in part), p. 806, pl. 1, fig. 1, 2 (not 7, 8).

Dictyocha stapedia aspinosa Bukry, Bukry, 1979a, p. 984, pl. 4, fig. 4-6.

\section{Dictyocha stapedia stapedia Haeckel}

(Plate 5, Figures 8-10)

Dictyocha stapedia Haeckel, 1887, p. 1561, pl. 101, fig. 10-12.

Dictyocha stapedia stapedia Haeckel, Bukry, 1976a, p. 724, pl. 3, fig. $1-7$.

\section{Genus DISTEPHANUS Stöhr, 1880}

\section{Distephanus boliviensis boliviensis (Frenguelli)}

(Plate 5, Figure 13; Plate 6, Figures 4-6)

Dictyocha boliviensis Frenguelli, 1940 (in part), p. 44, fig. 4a.

Distephanus boliviensis boliviensis (Frenguelli), Bukry, 1979a, p. 985, pl. 4, fig. 12; pl. 5, fig. 1 .

\section{Distephanus speculum minutus (Bachmann) (Plate 5, Figure 14)}

Dictyocha speculum f. minuta Bachmann in Ichikawa et al., 1967, p. 161 , pl. 7, fig. 12-15.

Distephanus speculum minutus (Bachmann), Bukry, 1976b, p. 895, pl. 8, fig. 1-3.

\section{Distephanus speculum pentagonus Lemmermann}

Distephanus speculum var. pentagonus Lemmermann, 1901, p. 265, pl. 11, fig. 19.

\section{Distephanus speculum speculum (Ehrenberg)}

(Plate 5, Figures 15, 16; Plate 6, Figures 1-3)

Dictyocha speculum Ehrenberg, 1839, p. 150; Ehrenberg, 1854, pl. 18, fig. 57 ; pl. 19 , fig. 41 ; pl. 21 , fig. 44 ; pl. 22, fig. 47.

Dictyocha aculeata Ehrenberg, 1840, p. 148; fide Loeblich et al. (1968), figured by Bailey, 1843, pl. 3, fig. 17; Ehrenberg, 1854, p. 19, fig. 40; pl. 21, fig. 47; pl. 22, fig. 48a-d.

Dictyocha aculeata Ehr., Stöhr, 1880, p. 120, pl. 7, fig. 7a, b.

Distephanus aculeatus (Ehrenberg) Haeckel, 1887, p. 1565.

Distephanus speculum var. aculeatus (Ehrenberg) Lemmermann, 1901 , p. 264 , pl. I1, fig. 23.

not Dictyocha fibula Ehrenberg var. aculeata Lemmermann 1901, p. 261, pl. 11, fig. $1,2$.

not Dictyocha fibula var. aculeata Lemm., Frenguelli, 1935, pl. 13, fig. 1-9.
Dictyocha speculum var. aculeata (Ehrenberg) Frenguelli, 1941, p. 94 , pl. 1 , fig. 6 .

not Dictyocha fibula var. aculeata Lemmermann, Ling, 1972, p. 161, fig. 16,17 .

not Dictyocha aculeata (Lemmermann) Dumitricá, 1973a, p. 907, pl. 9, fig. 5-10.

Distephanus aculeatus (Ehrenberg), Locker, 1974, pl. 3, fig. 5, 6, 9.

Remarks: Distephanus aculeatus (Ehrenberg) is a hexagonal silicoflagellate which was distinguished from $D$. speculum (Ehrenberg) only by the more prominent basal or apical pikes. Originally it was described, like D. speculum, in genus Dictyocha, but was transferred to Distephanus in 1887, soon after creation of the genus. Although $D$. aculeata (Ehrenberg) is a little-used concept, there has been no question about its affinities to the $D$. speculum group since Lemmermann recognized it as a variety within that species in 1901 .

\section{Distephanus sp. A Bukry}

(Plate 6, Figures 7-9)

Distephanus sp. A Bukry, 1979a, p. 985, pl. 5, fig. 7-10.

Genus MESOCENA Ehrenberg, 1843

\section{Mesocena circulus (Ehrenberg)}

(Plate 7, Figures 5-7)

Mesocena circulus (Ehrenberg) Ehrenberg, 1844, p. 65. Mesocena circulus (Ehrenberg), Bukry, 1975b, p. 868, pl. 6, fig. 1, 2.

Remarks: Sparse, short-spined forms of Mesocena circulus occur only in the basal Quaternary of Site 420 ? and 425 , in conjunction with the maximum Listephanus speculum speculum abundance at those sites. The distribution of $M$. circulus at Sites 157 and 321 in the Eastern Pacific suggests it was at the north tropical and temporal end of its range. At mid-latitude Site 310 on Hess Rise and Site 362 on Walvis Ridge it occurs consistently through the Pliocene up to the Pliocene/Pleistocene boundary (Bukry, 1978a).

\section{Mesocena quadrangula Ehrenberg ex Haeckel \\ (Plate 7, Figures 9-17; Plate 8, Figures 1-10)}

Mesocena quadrangula Ehrenberg ex Haeckel, 1887, p. 1556, Lemmermann, 1901, pl. 10, fig. 5-7, fide Loeblich et al., 1968, p. 57. Mesocena quadrangula Ehrenberg ex Haeckel, Bukry, 1978b, p. 819,

pl. 7, fig. 1-5.

Remarks: The distinction of Mesocena quadrangula from M. elliptica (see Bukry, 1978b) includes longer, more equant spines; more quadrate form; and more noded surface. The contrast is emphasized by comparison of the curvature of the inner periphery of the ring near the short axis; it is a flatter curvature, part of a continuous long segment of an ellipse, for lower Miocene M. elliptica populations (Bukry, 1978b, pl. 6, fig. 6-13), but is more angular or more sharply curved in Quaternary $M$. quadrangula populations (Plates 7 and 8).

\section{Genus OCTACTIS Schiller, 1926}

\section{Octactis pulchra Schiller}

(Plate 8, Figures 11, 12)

Octactis pulchra Schiller, 1926, p. 67, fig. C.

Octactis pulchra Schiller, Bukry, 1979a, p. 986, pl. 7, fig. 2, 3.

\section{ACKNOWLEDGMENTS}

I thank J. A. Barron for helpful discussions on siliceous biostratigraphy for Leg 54. This paper was improved by the critical reviews of R. Z. Poore and J. A. Barron, U.S. Geological Survey. Typing of the text and illustrations and editorial proofing were superbly done by Dorothy Blackstock, U.S. Geological Survey. The samples for this study were kindly provided by Roger Hekinian and B. R. Rosendahl, CoChief Scientists, through the auspices of James Natland, DSDP Staff Scientist for Leg 54. 


\section{REFERENCES}

Bailey, J. W., 1843. Notice of some new localities of Infusoria, fossil and Recent, American Journal of Science, v. 48, p. 321-343.

Bukry, D., 1975a. Coccolith and silicoflagellate stratigraphy, northwestern Pacific Ocean, Deep Sea Drilling Project Leg 32. In Larson, R. L., Moberly, R., et al., Initial Reports of the Deep Sea Drilling Project, v. 32: Washington (U.S. Government Printing Office), p. 677-701.

1975b. Silicoflagellate and coccolith stratigraphy, Deep Sea Drilling Project Leg 29. In Kennett, J. P., Houtz, R. E., et al., Initial Reports of the Deep Sea Drilling Project, v. 29: Washington (U.S. Government Printing Office), p. $845-872$.

1976a. Silicoflagellate and coccolith stratigraphy, southeastern Pacific Ocean, Deep Sea Drilling Project Leg 34. In Yeats, R. S., Hart, S. R., et al., Initial Reports of the Deep Sea Drilling Project, v. 34: Washington (U.S. Government Printing Office), p. 715-735.

1976b. Cenozoic silicoflagellate and coccolith stratigraphy, South Atlantic Ocean, Deep Sea Drilling Project Leg 36. In Hollister, C. D., Craddock, C., et al., Initial Reports of the Deep Sea Drilling Project, v. 35: Washington (U.S. Government Printing Office), p. 885917.

1977a. Coccolith and silicoflagellate stratigraphy, central North Atlantic Ocean, Deep Sea Drilling Project Leg 37. In Aumento, F., Melson, W. G., et al., Initial Reports of the Deep Sea Drilling Project, v. 37: Washington (U.S. Government Printing Office), p. \$17-927.

1977b. Coccolith and silicoflagellate stratigraphy, South Atlantic Ocean, Deep Sea Drilling Project Leg 39. In Supko, P. R., Perch-Nielsen, K., et al. Initial Reports of the Deep Sea Drilling Project, v. 39: Washington (U.S. Government Printing Office), p. 825-839.

1978a. Cenozoic silicoflagellate and coccolith stratigraphy, southeastern Atlantic Ocean, Deep Sea Drilling Project Leg 40. In Bolli, H. M., Ryan, W. B. F., et al., Initial Reports of the Deep Sea Drilling Project, v. 40: Washington (U.S. Government Printing Office), p. 635649.

1978b. Cenozoic coccolith and silicoflagellate stratigraphy, Deep Sea Drilling Project Leg 44. In Benson, W. E., Sheridan, R. E., et al., Initial Reports of the Deep Sea Drilling Project, v. 44: Washington (U.S. Government Printing Office), p. 807-864.

1979a. Comments on opal phytoliths and stratigraphy of Neogene silicoflagellates and coccoliths at Deep Sea Drilling Project Site 397 off northwest Africa. In Luyendyk, B. P., Cann, J. R., et al., Initial Reports of the Deep Sea Drilling Project, v. 49: Washington (U.S. Government Printing Office), p. 977-1010.

1979b. Coccolith and silicoflagellate stratigraphy, northern Mid-Atlantic Ridge and Reykjanes Ridge, Deep Sea Drilling Project Leg 49. In Luyendyk, B. P., Cann, J. R., et al., Initial Reports of the Deep Sea Drilling Project, v. 49: Washington (U.S. Government Printing Office), p. 551-582.

Bukry, D. and Foster, J. H., 1973. Silicoflagellate and diatom stratigraphy, Leg 16, Deep Sea Drilling Project. In van Andel, T. H., Heath, G. R., et al., Initial Reports of the Deep Sea Drilling Project, v. 16: Washington (U.S. Government Printing Office), p. 815-871.

Burckle, L. H., 1977. Pliocene and Pleistocene diatom datum levels from the equatorial Pacific, Quaternary Research, v. 7, p. $330-340$.
Dumitrică, P., 1973a. Miocene and Quaternary silicoflagellates in sediments from the Mediterranean Sea. In Ryan, W. B. F., Hsü, K. J., et al., Initial Reports of the Deep Sea Drilling Project, v. 13: Washington (U.S. Government Printing Office), p. 903-933.

1973b. Paleocene, late Oligocene and post-Oligocene silicoflagellates in southwestern Pacific sediments cored on DSDP Leg 21. In Burns, R. E., Andrews, J. E., et al., Initial Reports of the Deep Sea Drilling Project, v. 21: Washington (U.S. Government Printing Office), p. 837883.

Ehrenberg, C. G., 1839. Über die Bildung der Kreidefelsen und des Kreidemergels durch unsichtbare Organismen, $K$. Preuss. Akad. Wiss. Berlin Ber., Jahrg. 1838, p. 59-148. 1840. Über noch jetzt zahlreich lebende Thierarten der Kreidebildung und den Organismus der Polythalamien, K. Preuss. Akad. Wiss. Berlin Ber., Jahrg. 1839, p. 81-174. 1844. Untersuchungen uber die kleinsten Lebensformen im Quellenlande des Euphrats and Araxes, so wie uber eine an neuen Formen sehr reiche marine Tripelbildung von den Bermuda-Inseln vor., K. Preuss. Akad. Wiss. Berlin Ber., Jahrg. 1844, p. 253-275.

$1-374$.

1854. Mikrogeologie: Leipzig (Leopold Voss), p.

Frenguelli, J., 1935. Variaciones de Dictyocha fibula en el golfo de San Matias (Patagonia septentrional), Buenos Aires, Anales del Museo Argentino de Ciencias Naturales, v. 38 , p. $263-381$.

1940. Consideraciones sobre los silicoflagelados fosiles, Mus. La Plata Rev., Paleontol., v. 2, no. 7, p. 37-112. , 1941. Silicoflagellados y Radiolarios del Tripoli del valle de Til-til (Chile) Nota preliminar, La Plata Univ. Nac., Inst. Mus. La Plata, Notas, v. 6, Paleontol. no. 28, p. $93-100$.

1951. Silicoflagelados del Tripoli de Mejillones (Chile), Physis (Buenos Aires), v. 20, p. 272-284.

Gemeinhardt, K., 1930. Silicoflagellatae. In Rabenhorst, L. (Ed.), Kryptogamen-Flora von Deutschland, Osterreich und der Schweiz: Leipzig (Akad. Verlagsgesell.), v. 10, p. 1-87.

Haeckel, E. H. P. A., 1887. Cannorrhaphida, Challenger Report, v. 18 , p. $1546-1569$.

Hays, J. D., Saito, T., Opdyke, N. D., and Burckle, L. H., 1969. Pliocene-Pleistocene sediments of the equatorial Pacific: their paleomagnetic, biostratigraphic, and climatic record, Geological Society of America Bulletin, v. 80, p. 1481-1514.

Ichikawa, W., Shimizu, I., and Bachmann, A., 1967. Fossil silicoflagellates and their associated uncertain forms in Iida Diatomite, Noto Peninsula, Central Japan, Kanazawa University Science Reports, v. 12, p. 143-172.

Jousé, A. P. and Mukhina, V. V., 1973. The Mesocena elliptica Ehr. Zone in the Pleistocene sediments of the Pacific Ocean, Oceanology (AGU Translation), v. 13, p. 386-394.

LaBrecque, J. L., Kent, D. V., and Cande, S. C., 1977. Revised magnetic polarity time scale for Late Cretaceous and Cenozoic time, Geology, v. 5, p. 330-335.

Lanjouw, J., et al. (Eds.), 1966. International Code of Botanical Nomenclature adopted by the Tenth International Botanical Congress, Edinburgh, August 1964: Utrecht (International Bureau for Plant Taxonomy and Nomenclature).

Lemmermann, E., 1901. Silicoflagellatae, Deutsche. Bot. Gesell. Ber., v. 19, p. 247-271.

Ling, H. Y., 1970. Silicoflagellates from central North Pacific core sediments, Bulletins of American Paleontology, v. 58, p. 85-129. 
1972. Upper Cretaceous and Cenozoic silicoflagellates and ebridians, Bulletins of American Paleontology, v. 62 , p. $135-229$.

1975. Silicoflagellates and ebridians from Leg 31. In Ingle, J. C., Karig, D. E., et al., Initial Reports of the Deep Sea Drilling Project, v. 31: Washington (U.S. Government Printing Office), p. 763-777.

1976. Distribution and biostratigraphic significance of Dictyocha subarctios (silicoflagellate) in the North Pacific, Paleontological Society of Japan Transactions and Proceedings, N.S., no. 101, p. 264-270.

1977. Late Cenozoic silicoflagellates and ebridians from the eastern North Pacific region, 1st International Congress on Pacific Neogene Stratigraphy Proceedings, Tokyo, p. 205-233.

Locker, S., 1974. Revision der Silicoflagellaten aus der Mikrogeologischen Sammlung von C. G. Ehrenberg, Eclogae Geologicae Helvetiae, v. 67, p. 631-646.

Loeblich, A. R., 3d, Loeblich, L. A., Tappan, H., and Loeblich, A. R., Jr., 1968. Annotated index of fossil and recent silicoflagellates and ebridians with descriptions and illustrations of validly proposed taxa, Geological Society of America Memoir 106.

Martini, E., 1971. Neogene silicoflagellates from the equatorial Pacific. In Winterer, E. L., Riedel, W. R., et al., Initial Reports of the Deep Sea Drilling Project, v. 7; Part 2: Washington (U.S. Government Printing Office), p. 16951708.

1976. Cretaceous to recent calcareous nannoplankton from the central Pacific Ocean (DSDP Leg 33). In Schlanger, S. O., Jackson, E. D., et al., Initial Reports of the Deep Sea Drilling Project, v. 33: Washington (U.S. Government Printing Office), p. 383-423.

Mikkelsen, N., 1977. On the origin of Ethmodiscus ooze, Marine Micropaleontology, v. 2, p. 35-46.

1978. Preservation of diatoms in glacial to Holocene deep-sea sediments of the equatorial Pacific, Geology, v. 6, p. 553-555.
Perch-Nielsen, K., 1975. Late Cretaceous to Pleistocene silicoflagellates from the southern southwest Pacific, DSDP Leg 29. In Kennett, J. P., Houtz, R. E., et al., Initial Reports of the Deep Sea Drilling Project, v. 29: Washington (U.S. Government Printing Office), p. 677-721.

Poelchau, H. S., 1976. Distribution of Holocene silicoflagellates in North Pacific sediments, Micropaleontology, v. 22, p. 164-193.

Saito, T. and Burckle, L. H., 1977. Occurrence of silicoflagellate Mesocena elliptica, Geological Society of Japan Journal, v. 83, p. 181-186.

Schiller, J., 1926. Die planktontischen Vegetation des adriatischen Meers.: B. Chrysomonadina, Heterokontae, Cryptomonadina, Eugleninae, Volvocales. I. Systematischer Teil., Arch. Protistenk, v. 53, p. 59-123.

Schulz, P., 1928. Beitrage zur Kenntnis fossiler und rezenter Silicoflagellaten, Bot. Archiv, v. 21, p. 225-292.

Schackleton, N. J. and Opdyke, N. D., 1976. Oxygen-isotope and paleomagnetic stratigraphy of Pacific core V28-239 late Pliocene to latest Pleistocene, Geological Society of America Memoir 145, p. 449-464.

Stöhr, E., 1880. Die Radiolarien Fauna der Tripoli von Grotte, Provinz Girgenti in Sicilien, Palaeontographica, v. 26, p. 71-124.

Stoll, N. R., et al. (Eds.), 1964. International Code of Zoological Nomenclature adopted by the XV International Congress of Zoology: London (International Commission on Zoological Nomenclature).

Stradner, H. and Bachmann, A., 1978. Late Pliocene and early Pleistocene silicoflagellates and ebridians from DSDP Site 378 in the Aegean Basin, north of Crete. In Hsü, K. J., Montadert, L., et al., Initial Reports of the Deep Sea Drilling Project, v. 42, Part 1: Washington (U.S. Government Printing Office), p. 805-815.

Tampieri, R., 1972. Fitoplancton vivente nel Mediterraneo silicoflagellati, Giornale di Geologia, v. 38, p. 375-394.

Tsumura, K., 1963. A systematic study of Silicoflagellatae, Yokohama Municipal University Journal, ser. C-45, no. 146, p. $1-84$. 


\section{PLATE 1}

Silicoflagellates from DSDP Leg 54.

All figures magnified $\times 800$; scale bar equals $10 \mu \mathrm{m}$.

Figures 1-3 Dictyocha aculeata aculeata (Lemmermann).

1, 2. Normal, Sample 425-1-1, 60-62 cm (1 m).

3. Cruxoid, Sample 425-3-2, 74-76 cm (27 m).

Figures 4-7 Dictyocha sp. aff. D. aculeata (Lemmermann).

4. Irregular, Sample 425-1-2, 110-112 cm (3 m).

5. Sample 425-3-6, $74-76 \mathrm{~cm}(33 \mathrm{~m})$.

6 , 7. Long-barred, Sample 425-3-5, $74-76 \mathrm{~cm}$ $(31 \mathrm{~m})$.

Figures 8-17 Dictyocha aculeata subaculeata n. subsp.

8. Holotype, USNM 258919, Sample 425-4-2, $74-76 \mathrm{~cm}(46 \mathrm{~m})$.

9. USNM 258920, Sample 425-3-6, 74-76 cm (33 m).

10. USNM 258921, Sample 425-3-3, 74-76 cm (28 m).

11. USNM 258922, Sample 427-3-2, 70-72 cm (15 m).

12. USNM 258923, Sample 425-2-3, 74-76 cm $(9 \mathrm{~m})$.

13. USNM 258924, Sample 425-1-1, 60-62 cm (1 m).

14. USNM 258925, Sample 425-1-1, 60-62 cm (1 m).

15. USNM 258926, Sample 419-4-5, 89-91 cm $(26 \mathrm{~m})$.

16. USNM 258927, Sample 425-3-2, 74-76 cm $(27 \mathrm{~m})$.

17. USNM 258928, Sample 425-2-3, 74-76 cm (9 m). 
PLATE 1
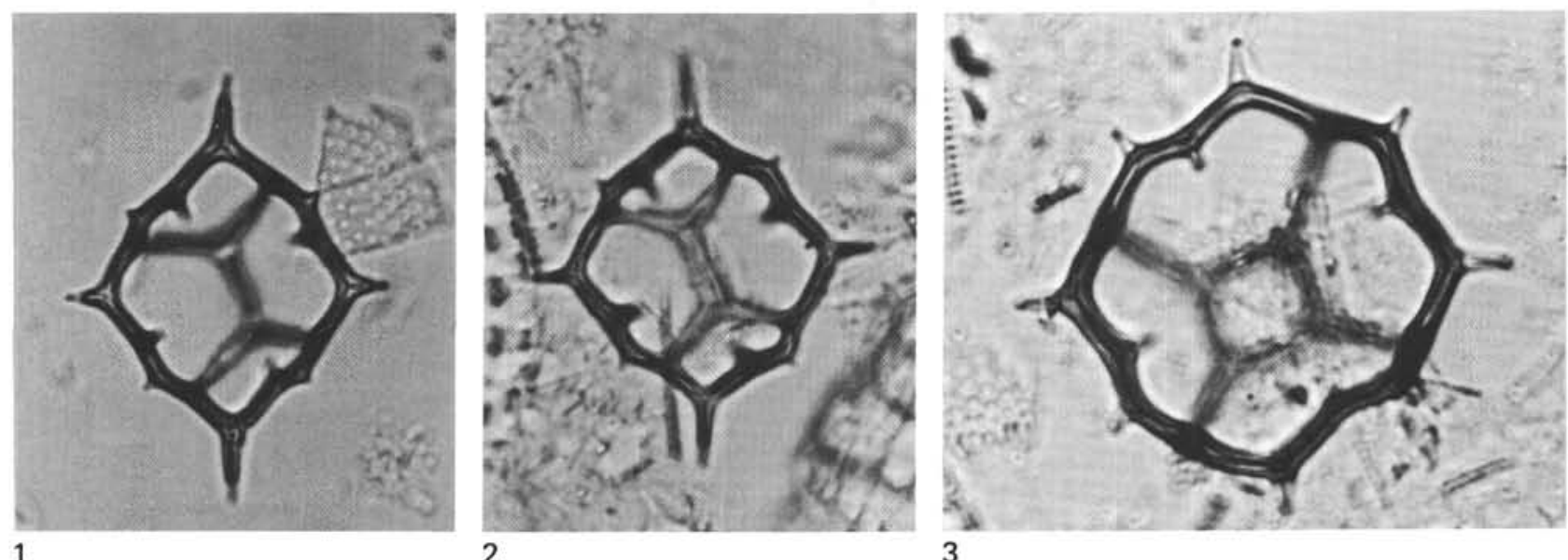

3
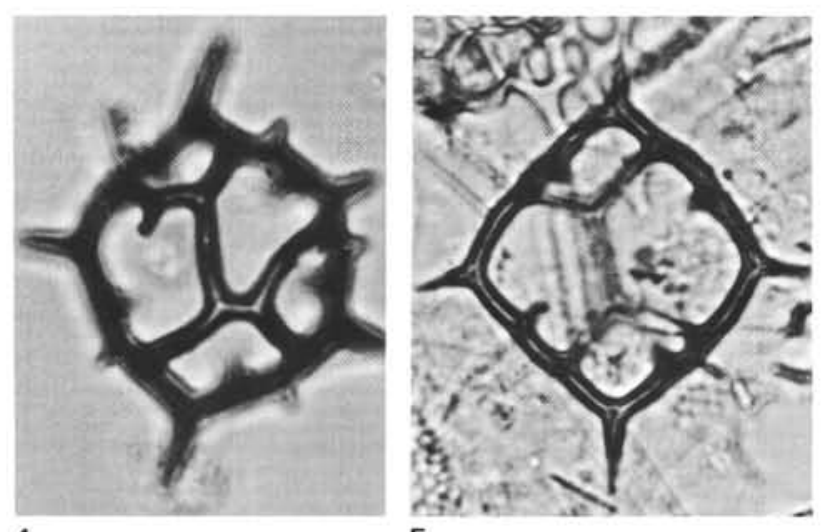

5
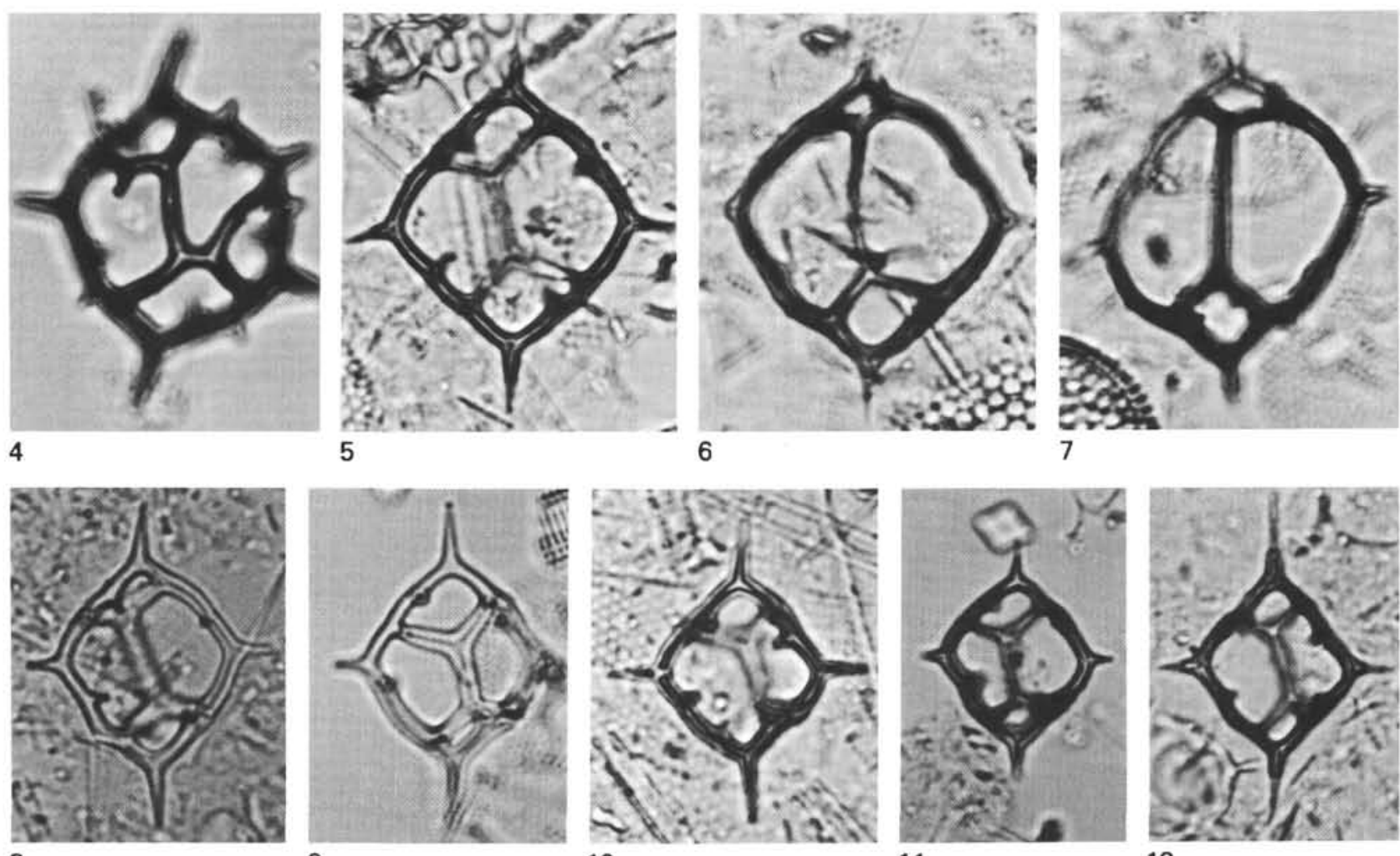

10

11

12
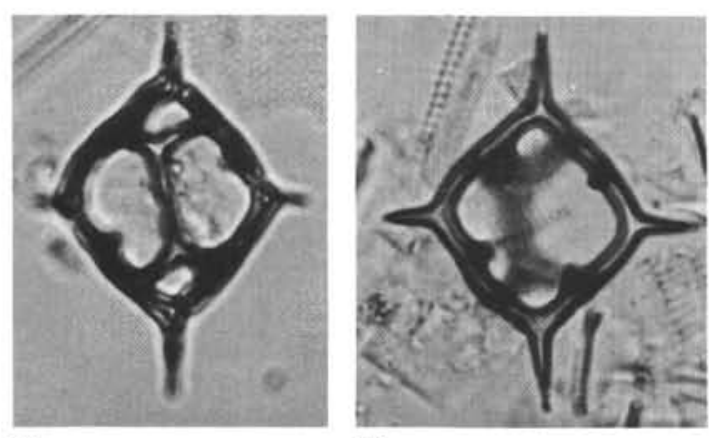

14

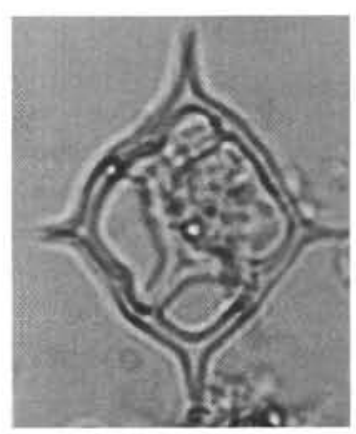

15
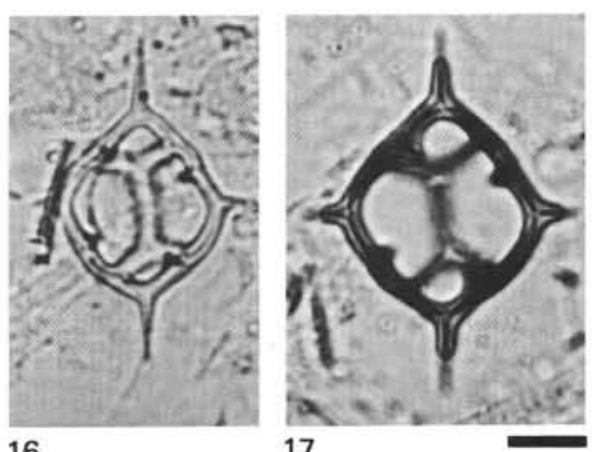
PLATE 2

Silicoflagellates from DSDP Leg 54.

All figures magnified $\times 800$; scale bar equals $10 \mu \mathrm{m}$.

Figure $1 \quad$ Dictyocha aspera (Lemmermann).

Sample 425-6-1, 74-76 cm (73 m).

Figure 2 Dictyocha brevispina (Lemmermann). Sample 425-6-2, 74-76 cm (74 m).

Figure 3 Dictyocha calida calida Poelchau. Sample 428-4-1, 74-76 cm (49 m).

Figures 4, $5 \quad$ Dictyocha sp. cf. D. calida calida Poelchau. Thick barred.

4. Sample 425-3-1, 74-76 cm (25 m).

5. Sample 419-4-1, 124-126 cm (21 m).

Figures 6-8 Dictyocha calida ampliata Bukry.

6. Sample 420-7-1, 124-126 cm (53 m).

7. Sample 419-4-5, 89-91 cm (26 cm).

8. Sample 425-3-1, 74-76 cm (25 m). 
PLATE 2
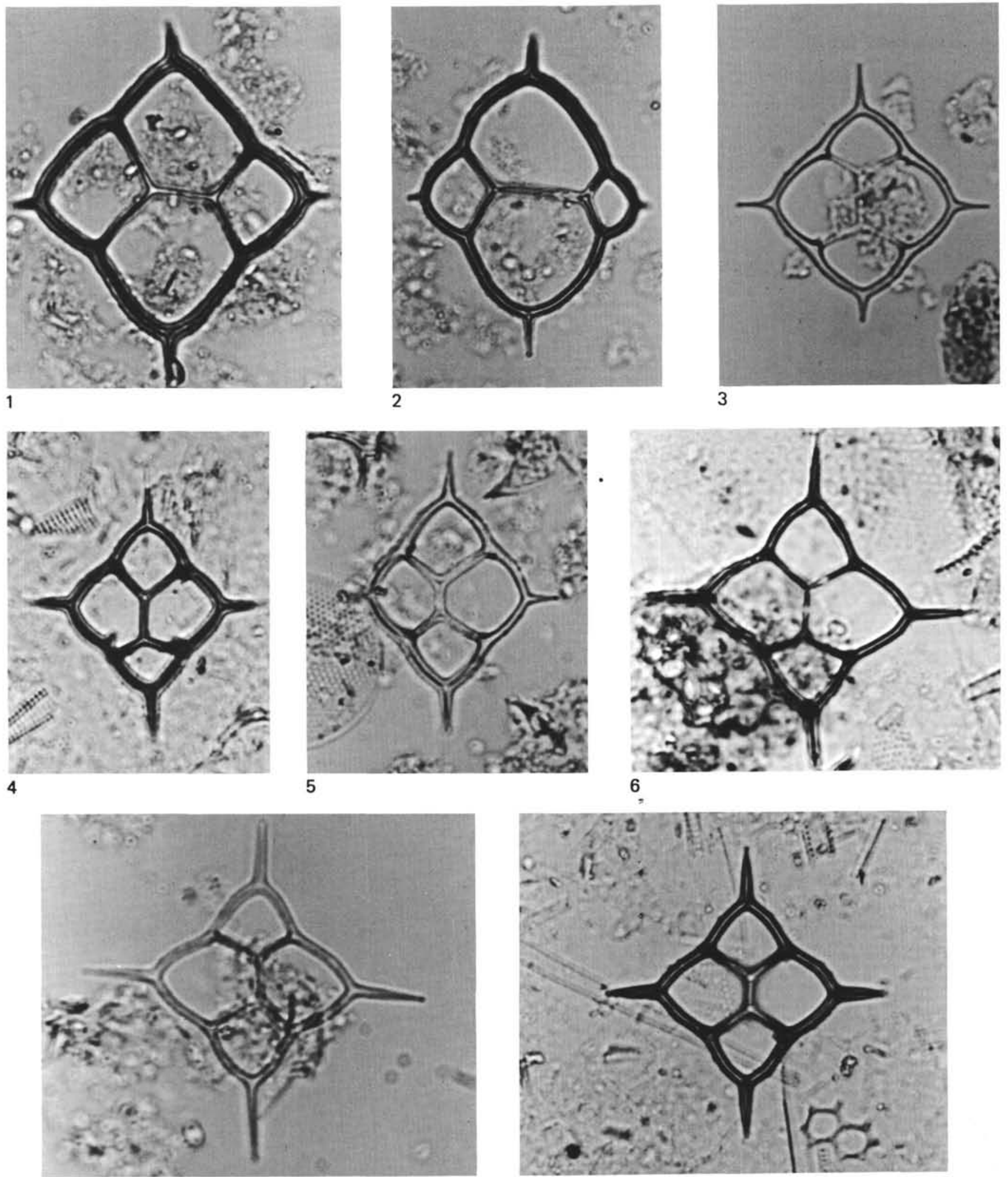

7

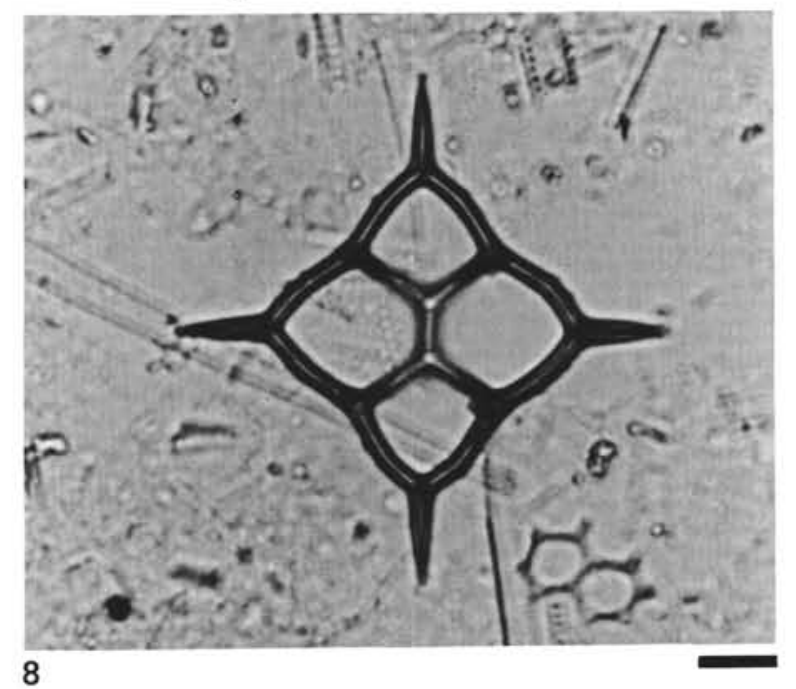


PLATE 3

Silicoflagellates from DSDP Leg 54.

All figures magnified $\times 800$; scale bar equals $10 \mu \mathrm{m}$.

Figures 1-4 Dictyocha hessii Bukry.

Sample 425-5-3, 74-76 cm (66 m).

1, 2. Pike location transitional to $D$. lingii.

3 , 4. Pike and bar transitional to $D$. lingii.

Figures 5-7 Dictyocha lingii Dumitricà.

5, 6. Low and high focus, Sample 422-4-2, $120-121 \mathrm{~cm},(28 \mathrm{~m})$.

7. Sample 419-4-1, 124-126 cm (21 m).

Figures 8-12 Dictyocha perlaevis delicata Bukry.

8 , 9. Sample 425-5-3, 74-76 cm (66 m).

10. Sample $425-5-4,74-76 \mathrm{~cm}(68 \mathrm{~m})$.

11. Variant, Sample 425-5-2, 74-76 cm (65 m).

12. Variant, Sample 425-5-3, $74-76 \mathrm{~cm}(66 \mathrm{~m})$. 
PLATE 3

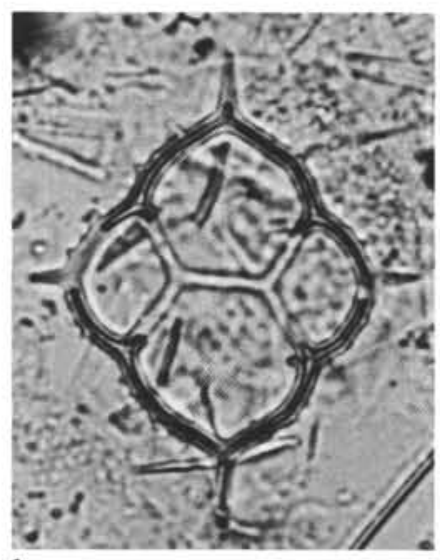

1

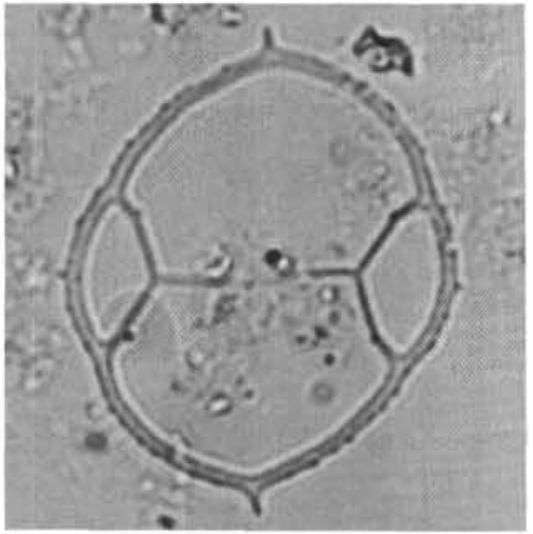

5

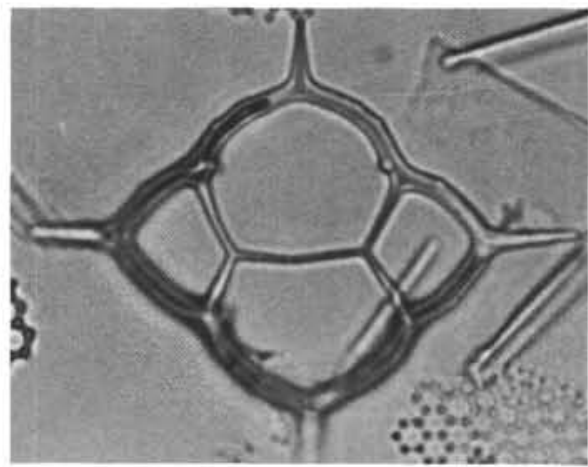

8

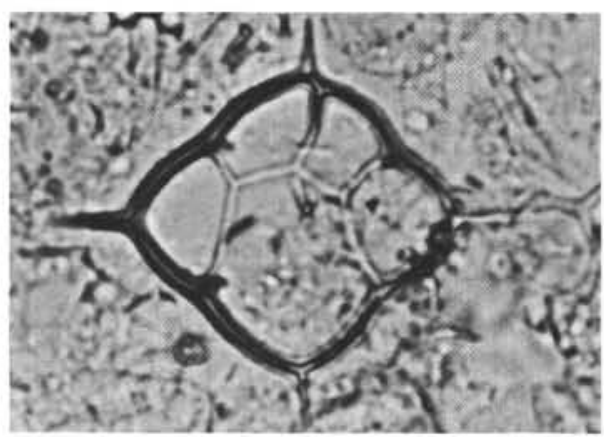

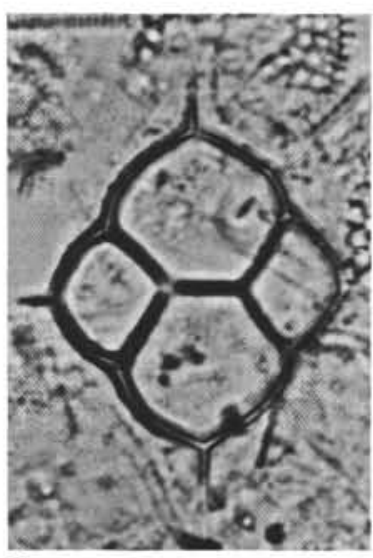

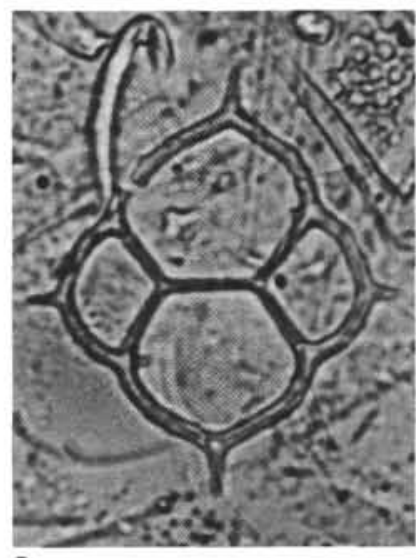

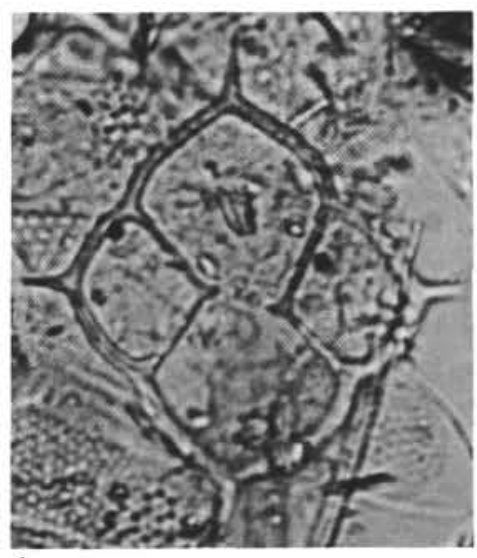

4

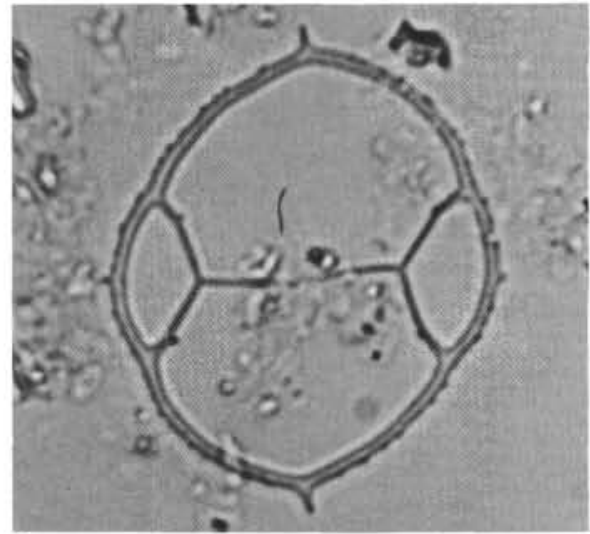

6
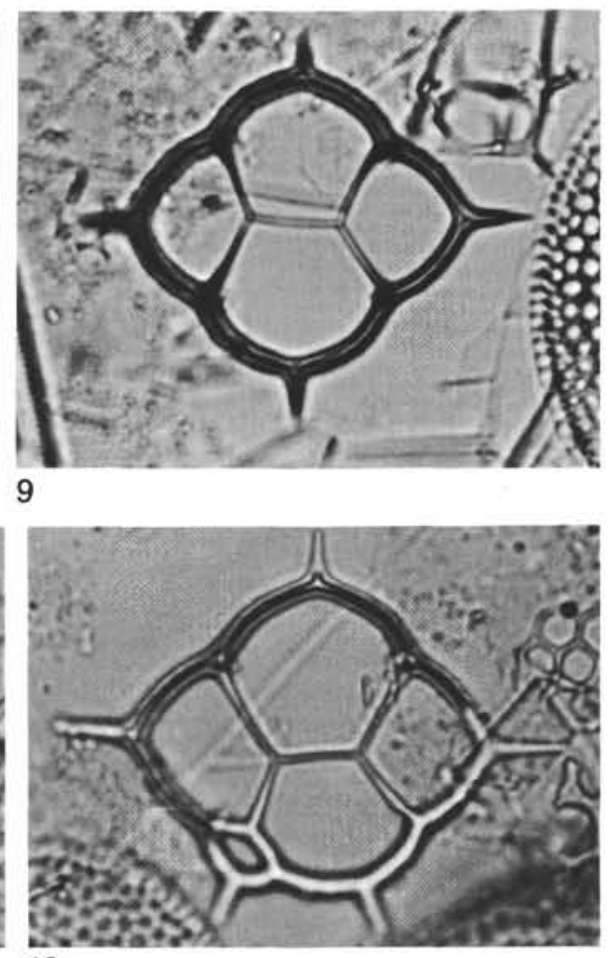

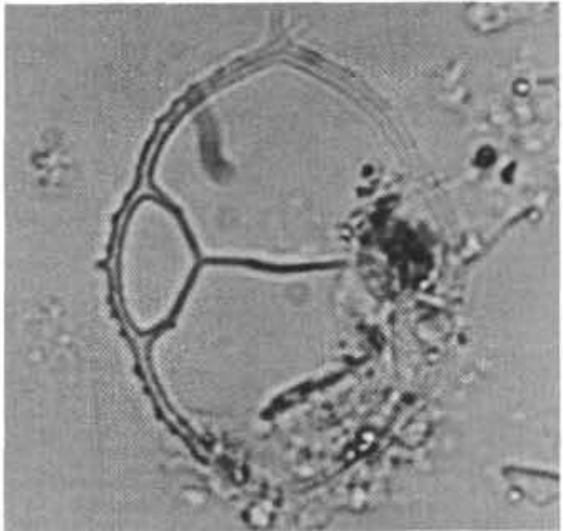

7

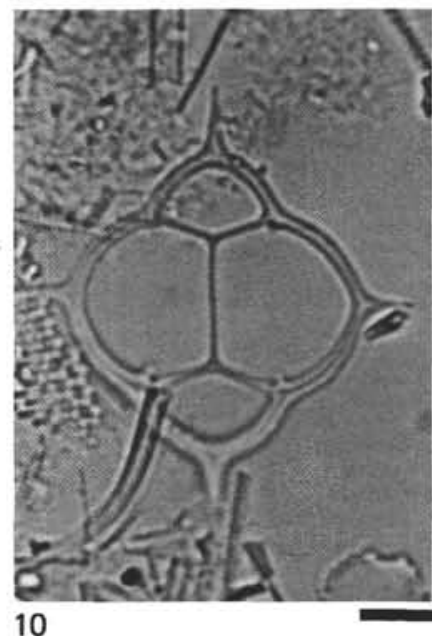


PLATE 4

Silicoflagellates from DSDP Leg 54.

All figures magnified $\times 800$; scale bar equals $10 \mu \mathrm{m}$.

Figures 1, 2 Dictyocha perlaevis ornata Bukry.

Sample 425-6-1, 74-76 cm (73 m).

Figures 3-9 Dictyocha perlaevis perlaevis Frenguelli.

3. Sample 425-4-1, 74-76 cm (44 m).

4. Sample 425-3-2, $74-76 \mathrm{~cm}(27 \mathrm{~m})$.

5. Sample 425-5-4, 74-76 cm (68 m).

6, 8. Sample $425-6-1,74-76 \mathrm{~cm}(73 \mathrm{~m})$.

7. Sample 425-3-6, 74-76 cm (33 m).

9. Variant, Sample 419-5-2, 69-71 cm (31 m).

Figures 10-13 Dictyocha perlaevis perlaevis Frenguelli.

Elongate variation (some have small spire).

10, 11. Sample 425-6-1, $74-76 \mathrm{~cm}(73 \mathrm{~m})$.

12 , 13. Sample 425-6-2, $74-76 \mathrm{~cm}(74 \mathrm{~m})$. 
PLATE 4

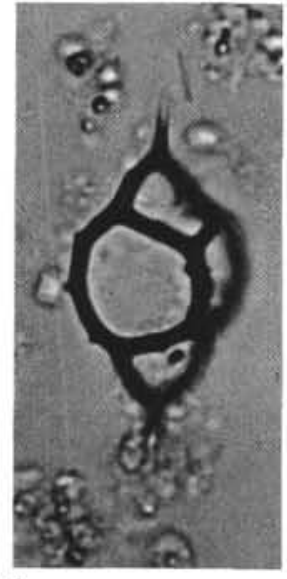

1

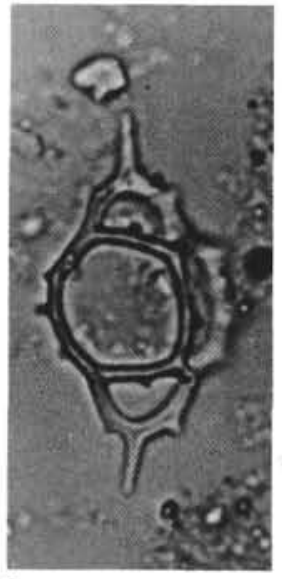

2
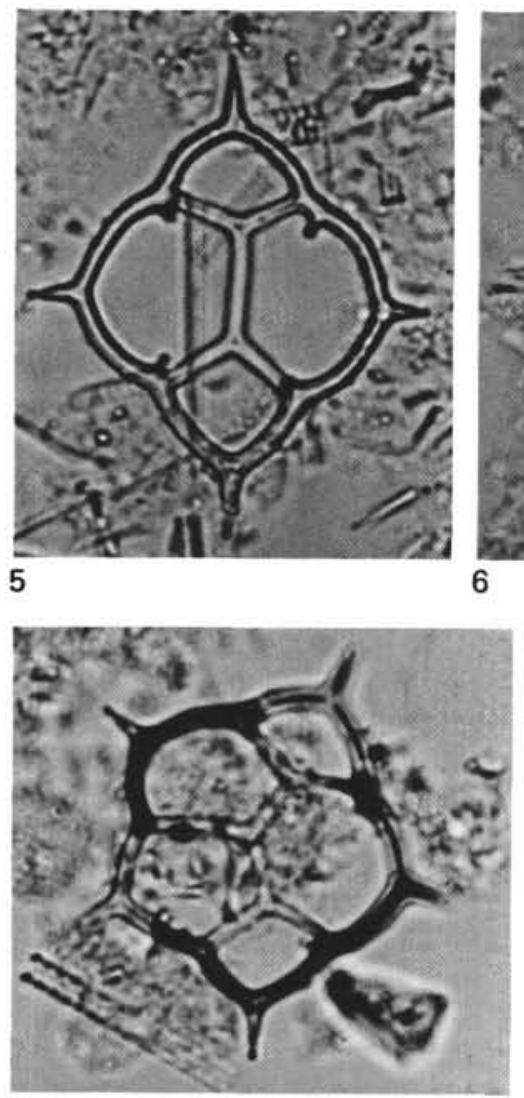

9

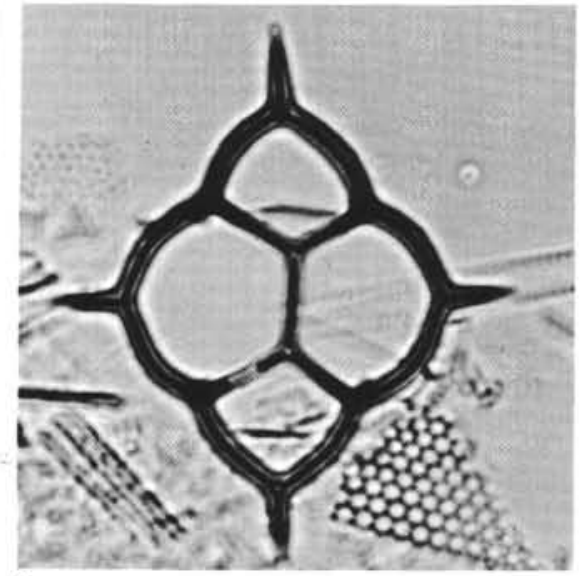

3
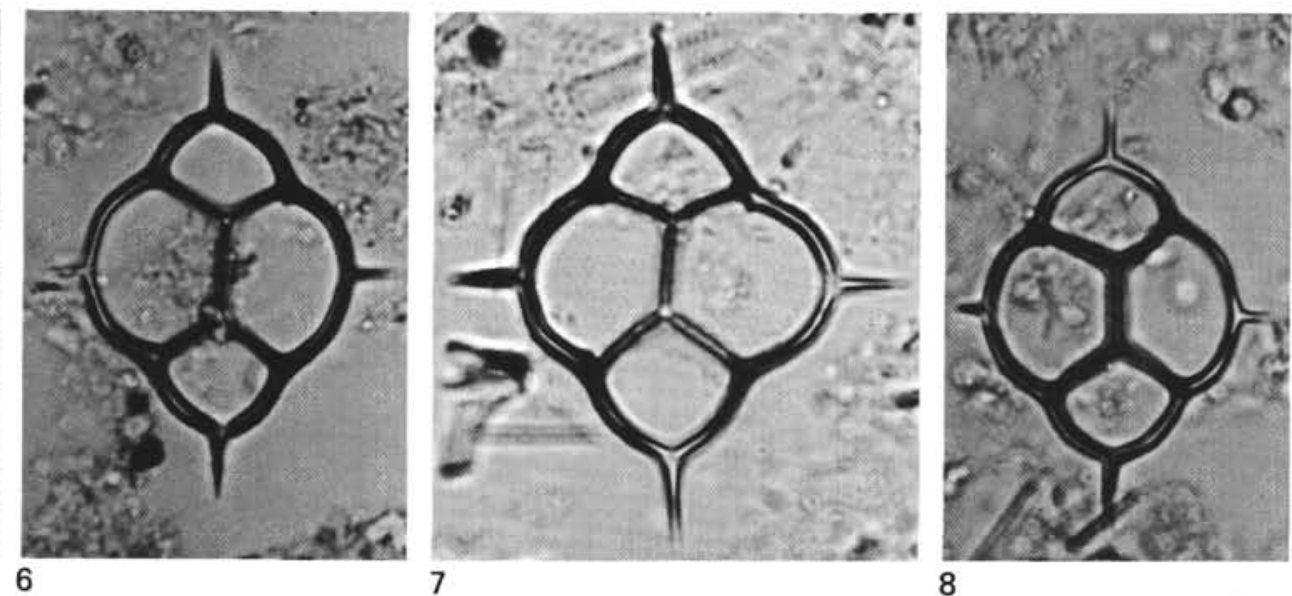

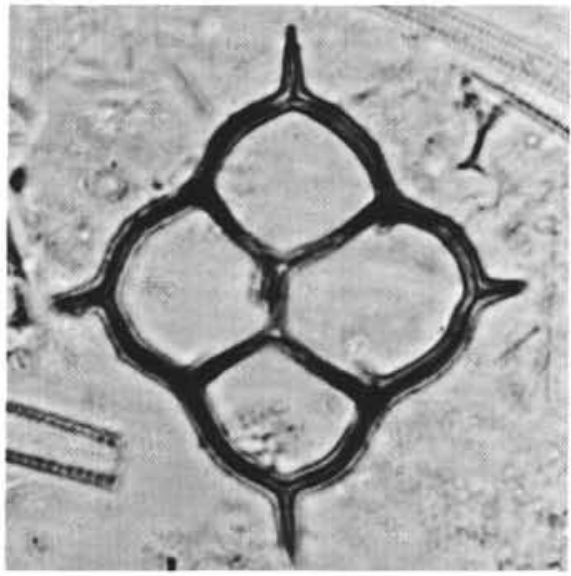

4

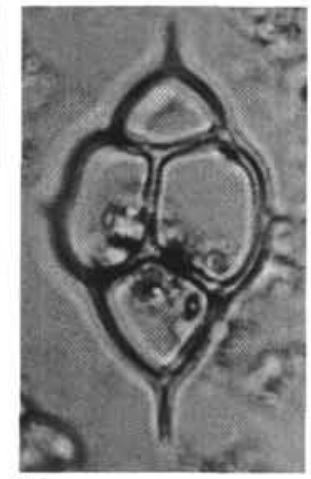

10

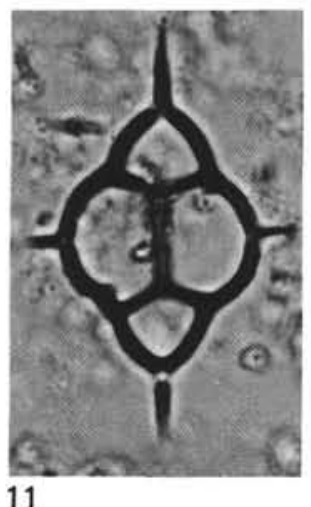

11

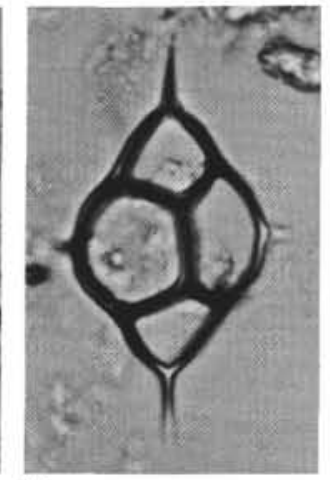

12 
PLATE 5

Silicoflagellates from DSDP Leg 54.

Figures 1-12, 14-16 magnified $\times 800$, scale bar equals $10 \mu \mathrm{m}$.

Figure 13 magnified $\times 550$; scale bar equals $20 \mu \mathrm{m}$.

Figures 1-3 Dictyocha perlaevis perlaevis Frenguelli.

1. Crinkled, Sample 420-5-2, 122-124 cm (36 m).

2. Arrowhead, Sample 420-8-5, 122-124 cm (69 m).

3. Five-strut, Sample 425-3-1, 74-76 cm (25 m).

Figures 4-7 Dictyocha stapedia aspinosa Bukry.

4. Sample 425-3-1, 74-76 cm (25 m).

5 , 6. Sample $425-3-3,74-76 \mathrm{~cm}(28 \mathrm{~m})$.

7. Sample $425-3-4,74-76 \mathrm{~cm}(30 \mathrm{~m})$.

Figures 8-10 Dictyocha stapedia stapedia Haeckel.

8. Sample 420-10-1, 124-126 cm (82 m).

9. Sample 425-4-1, 74-76 cm (44 m).

10. Cruxoid, Sample 427-7-3, $74-76 \mathrm{~cm}(93 \mathrm{~m})$.

Figures 11, 12 Dictyocha sp. (naviculopsoid).

11. Sample 425-5-4, 74-76 cm (68 m).

12. Sample $425-4-3,74-76 \mathrm{~cm}(47 \mathrm{~m})$.

Figure 13 Distephanus boliviensis boliviensis (Frenguelli). Sample 428-4-5, 74-76 cm (55 m).

Figure 14 Distephanus speculum minutus Bachmann.

Sample 425-1-2, 110-112 cm (3 m).

Figures 15, 16 Distephanus speculum speculum (Ehrenberg).

15. Small form that predominates at Sites 420 and 428, Sample 425-4-1, 74-76 cm (44 m).

16. Oblique view of elongate specimens that occur only in Sample 425-6-2, 74-76 cm (74 m), where elongate Dictyocha perlaevis perlaevis is abundant. See also Plate 6, Figures 1, 2. 
PLATE 5
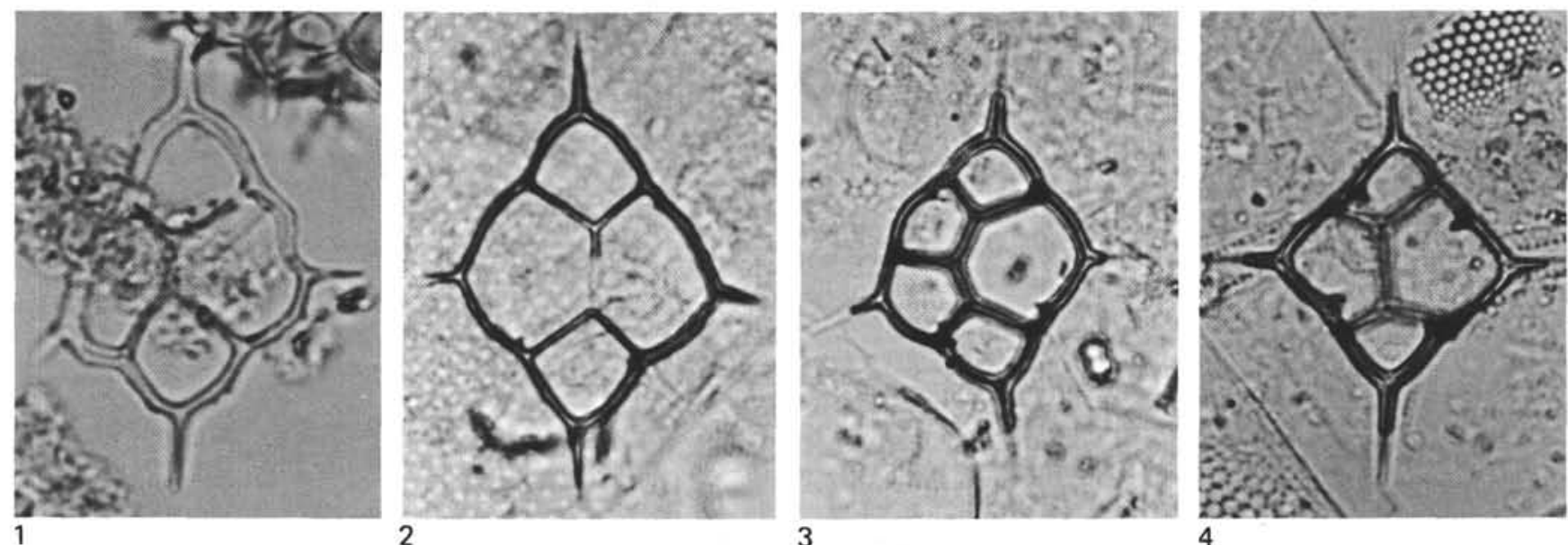

2
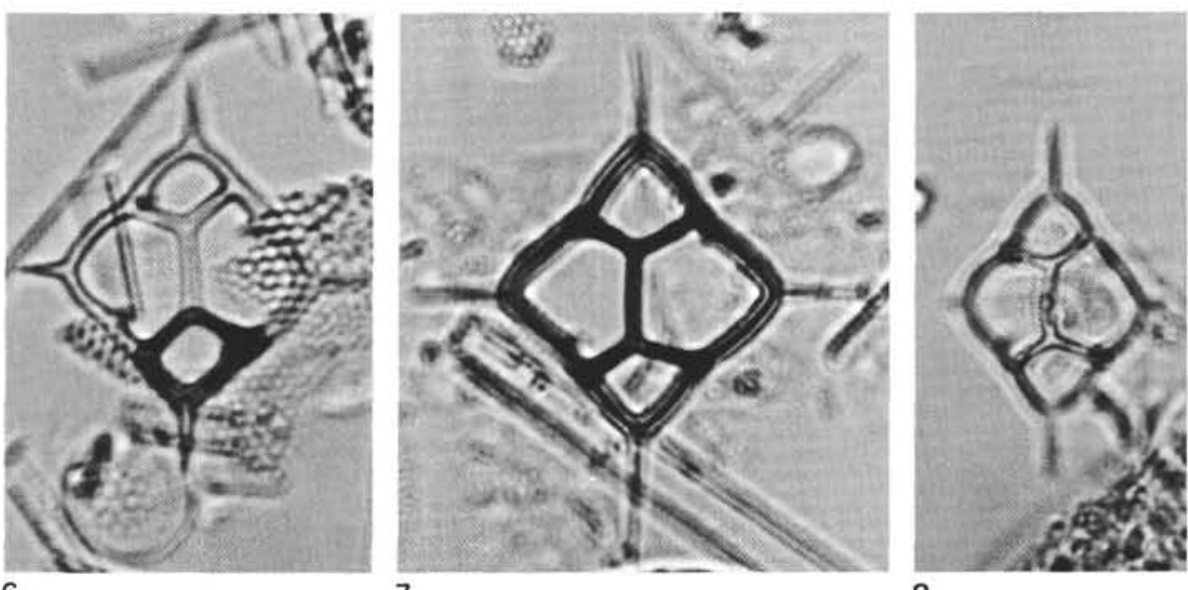

6

7

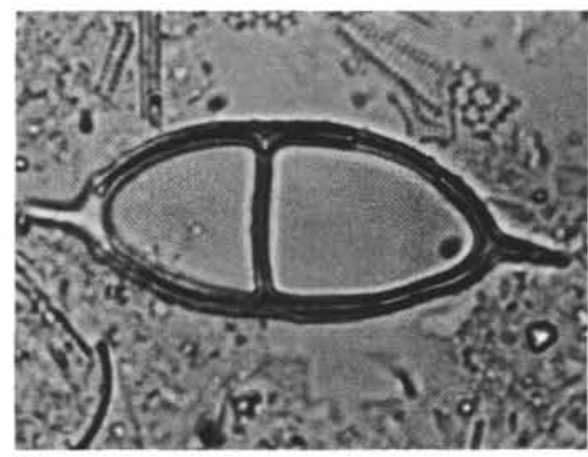

11

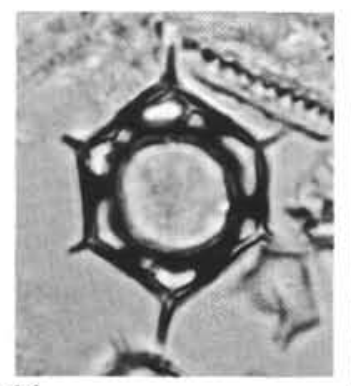

14

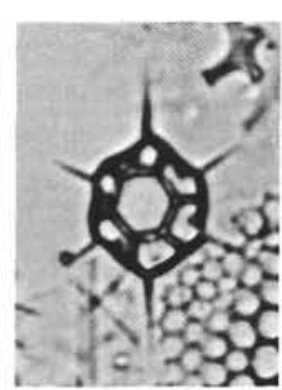

15

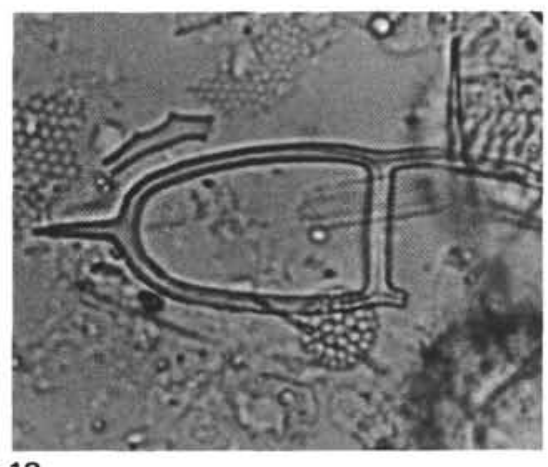

12

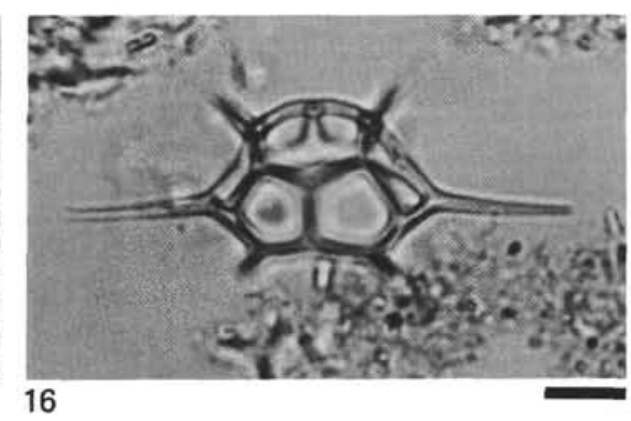


PLATE 6

Silicoflagellates from DSDP Leg 54.

All figures magnified $\times 800$; scale bar equals $10 \mu \mathrm{m}$.

Figures 1, 2 Distephanus speculum speculum (Ehrenberg). Elongated axial spine form found only in Sample 425-6-2, 74-76 cm (74 m), where elongate Dictyocha perlaevis perlaevis is most abundant.

Figure 3 Distephanus speculum speculum (Ehrenberg) at left and elongate Distephanus boliviensis boliviensis (Frenguelli) at right. Sample 425-6-1, 74-76 cm (73 m).

Figures 4-6 Distephanus boliviensis boliviensis (Frenguelli). Note that spine pairs lack radial symmetry through center point shown by $D$. speculum speculum.

4. Sample $425-5-2,74-76 \mathrm{~cm}(65 \mathrm{~m})$.

5, 6. Apical and basal focuses, Sample 425-3-5, $74-76 \mathrm{~cm}(31 \mathrm{~m})$.

Figures 7-9 Distephanus sp. A Bukry (1979).

7. Sample 428-4-3, 74-76 cm (52 m).

8. Ethmodiscus rex diatom fragment in background, Sample 420-8-5, 122-124 cm (69 m).

9. Sample $425-5-4,74-76 \mathrm{~cm}$ (68 m). 
PLATE 6

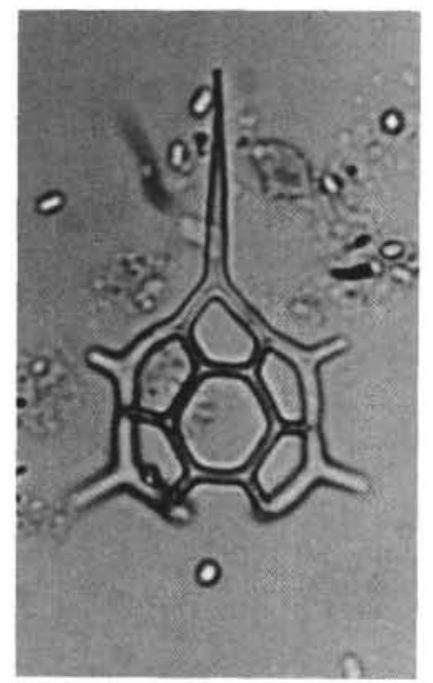

1
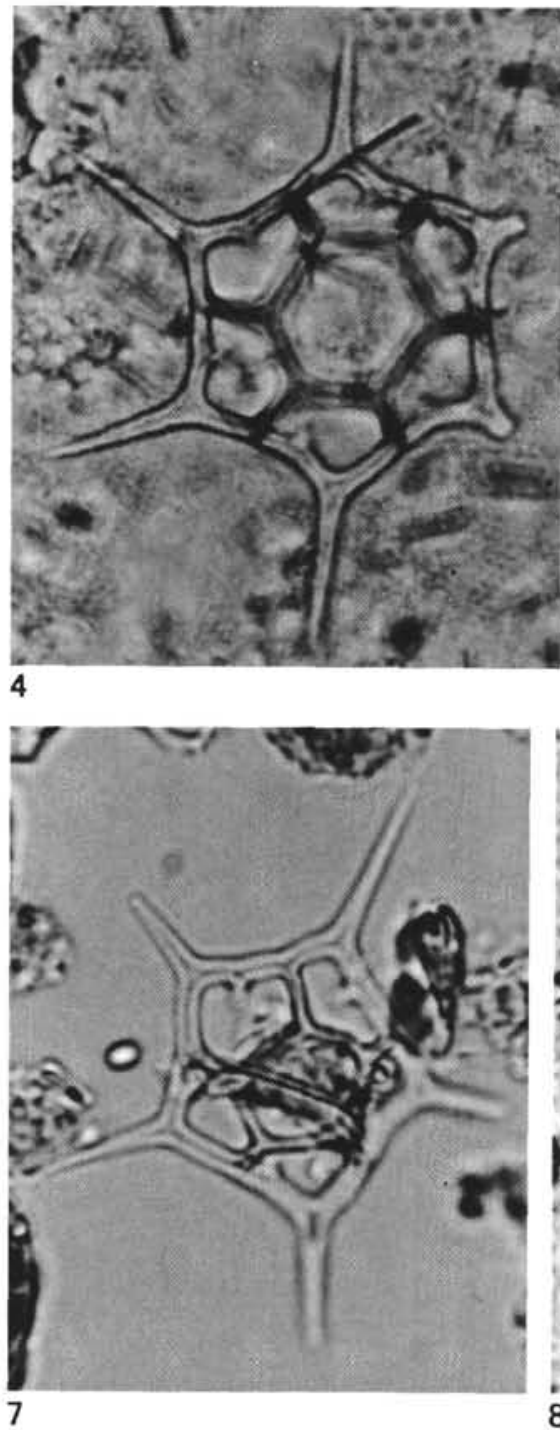

2
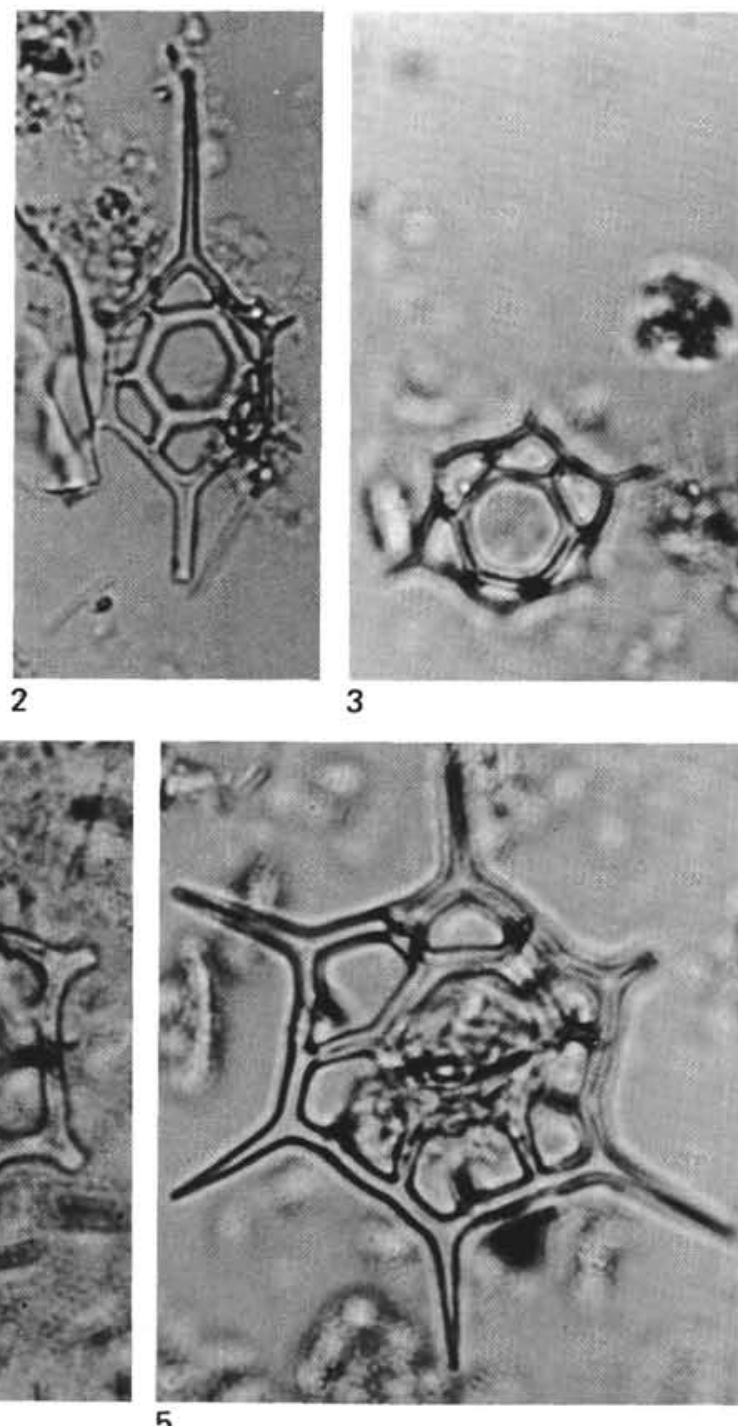

5

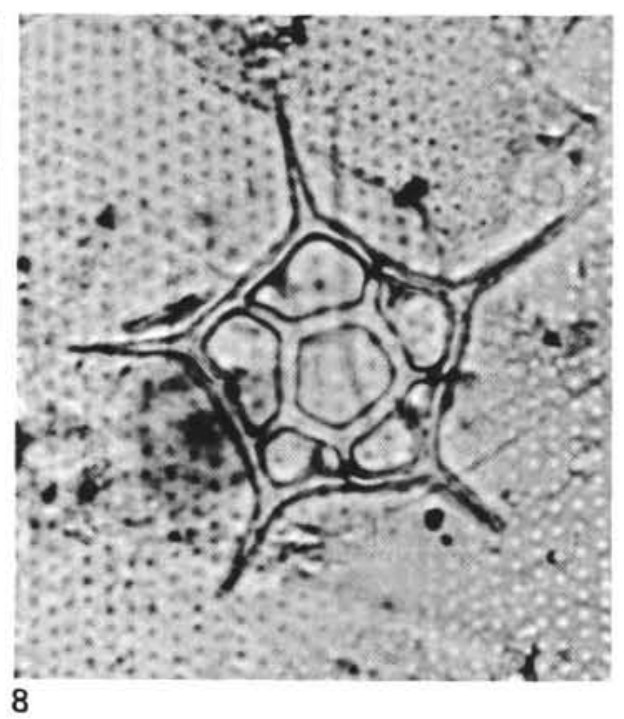

3
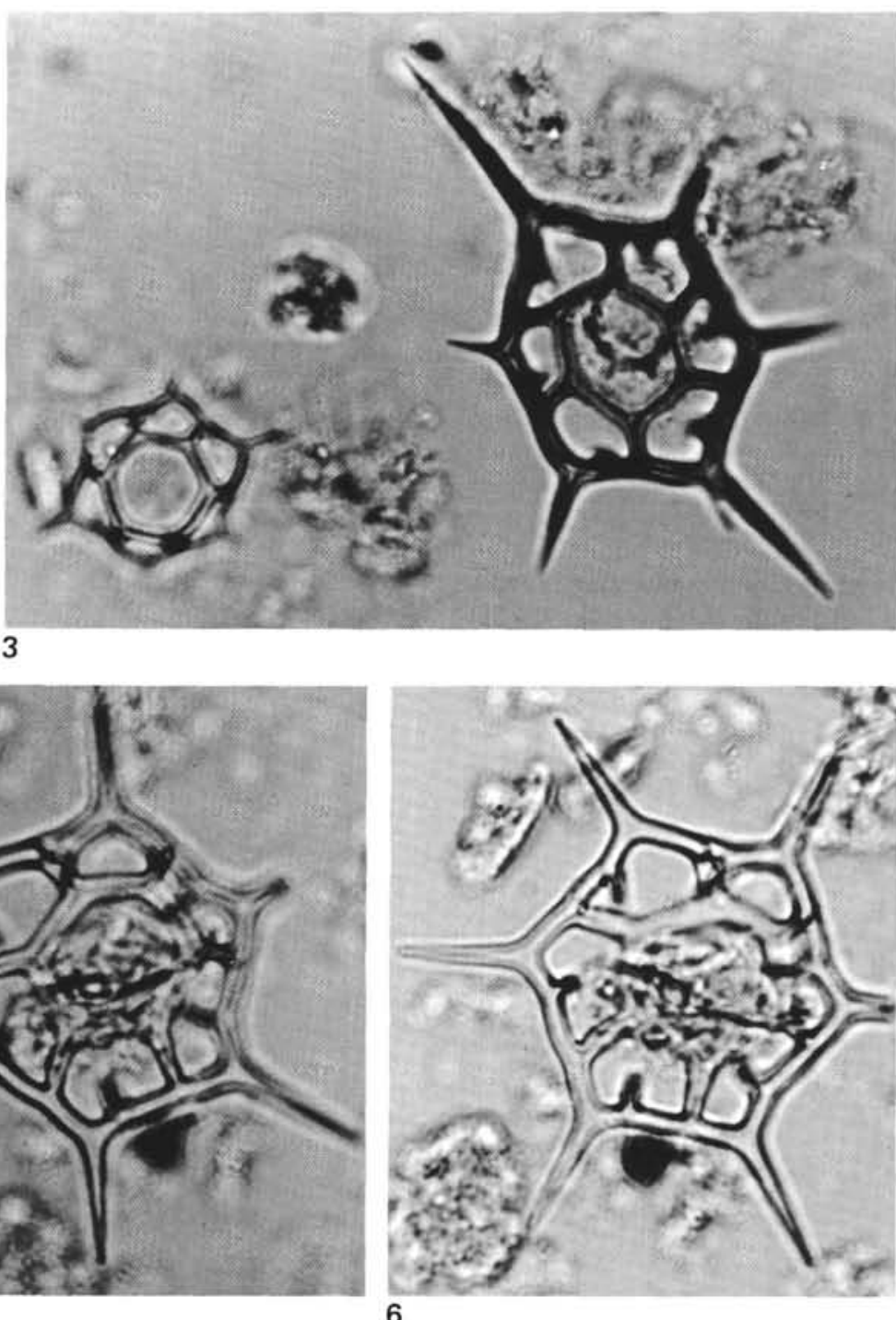

6

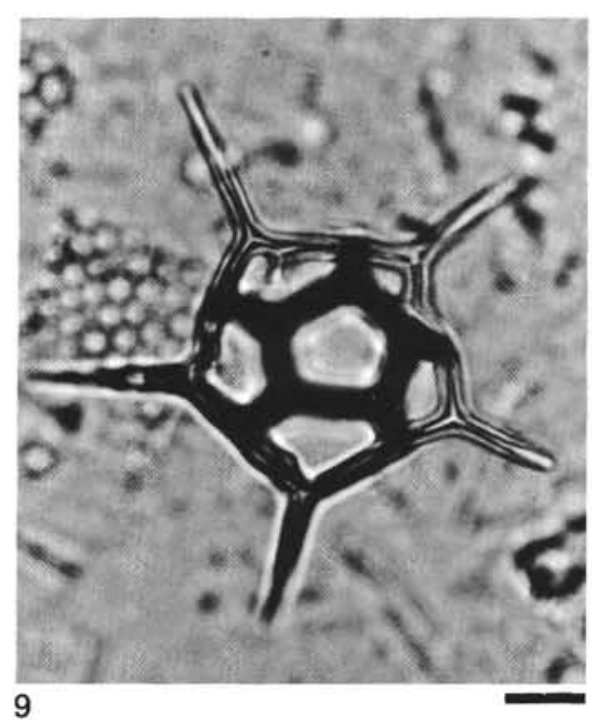


PLATE 7

Silicoflagellates from DSDP Leg 54.

All figures magnified $\times 800$; scale bar equals $10 \mu \mathrm{m}$.

Figures 1-4 Distephanus sp. (cruxoid).

1. Sample 425-4-3, 74-76 cm (47 m).

2. D. stapedia variant?, Sample 420-7-1, 124-126 $\mathrm{cm}(53 \mathrm{~m})$.

3. Sample 425-6-2, 74-76 cm (74 m).

4. Sample $425-6-1,74-76 \mathrm{~cm}(73 \mathrm{~m})$.

Figures 5-7 Mesocena circulus (Ehrenberg).

Sample 425-6-1, 74-76 cm (73 m).

Figure $8 \quad$ Mesocena sp. (one-spined).

Sample 420-10-5, 122-124 cm (88 m).

Figures 9-17 Mesocena quadrangula Ehrenberg ex Haeckel.

9. Sample 425-4-3, 74-76 cm (47 m).

$10,14,17$. Sample 420-7-1, 124-126 cm (53 m).

$11,15,16$. Sample 419-4-4, 132-134 cm (25 m).

12. Sample 425-4-2, 74-76 cm (46 m).

13. Sample $428-3-1,74-76 \mathrm{~cm}$ (39 m). 
PLATE 7
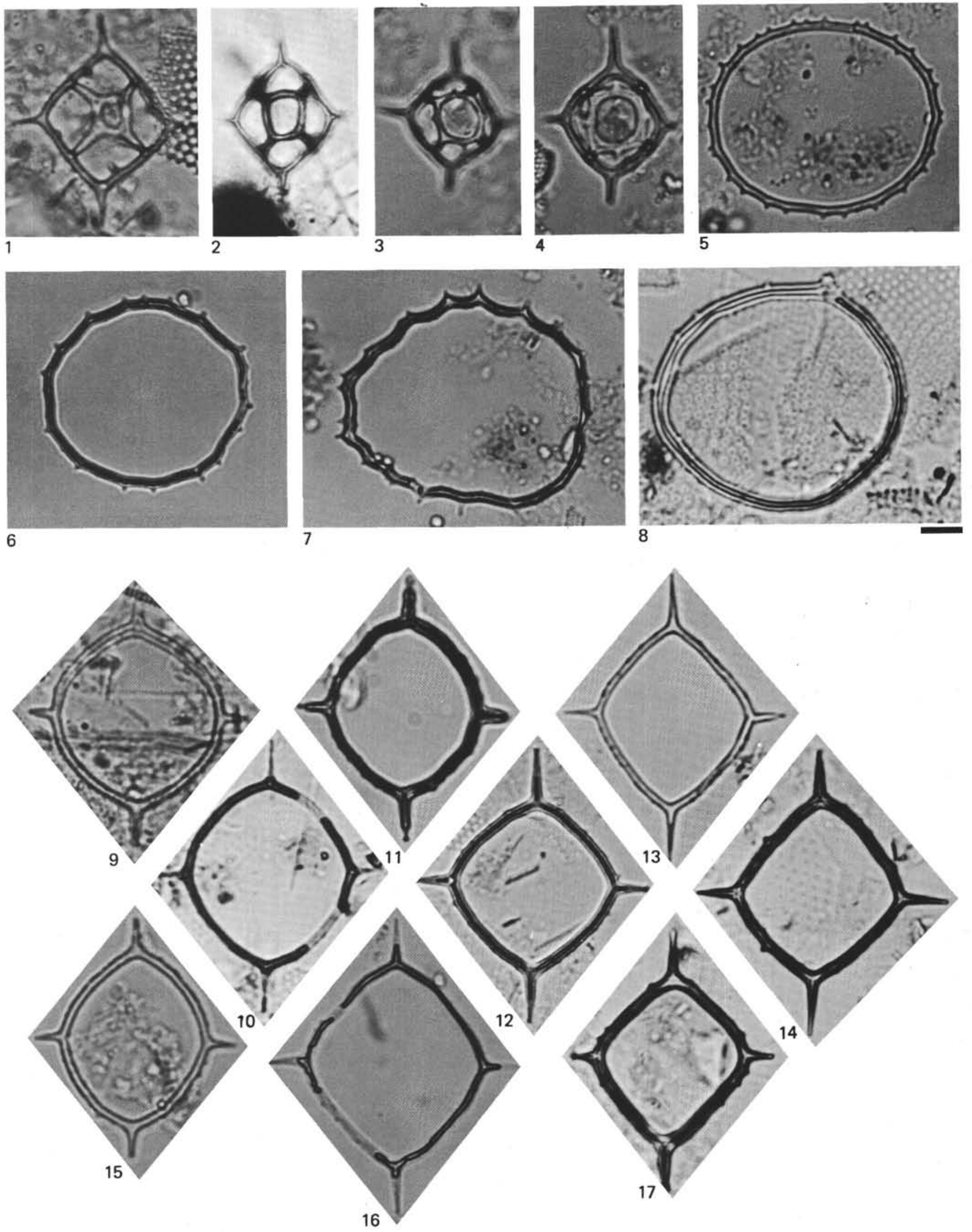


\section{PLATE 8}

Silicoflagellates from DSDP Leg 54.

All figures magnified $\times 800$; scale bar equals $10 \mu \mathrm{m}$.

Figures 1-10 Mesocena quadrangula Ehrenberg ex Haeckel. Low-frequency or unique variants.

1. Noded, see Mesocena elliptica verrucosa of Dumitrică (1973a), Sample 419-4-5, 89-91 cm (26 m).

2. Indented quadrant, Sample $425-5-3,74-76 \mathrm{~cm}$ $(66 \mathrm{~m})$. Recorded elsewhere near the beginning of the Mesocena quadrangula Zone in Samples 425-5-1, 74-76 cm (63 m); 427-8-4, $74-76 \mathrm{~cm}(123 \mathrm{~m})$; and $428-3-1,74-76 \mathrm{~cm}$ (39 m).

3, 6. Sample 425-5-1, 74-76 cm (63 m).

4. Sample $420-5-2,122-124 \mathrm{~cm}(36 \mathrm{~m})$.

5. Four symmetric nodes, Sample 428-4-1, 74-76 $\mathrm{cm}(49 \mathrm{~m})$.

7. Sample 425-5-2, 74-76 cm (65 m).

8. Sample 425-4-1, 74-76 cm (44 m).

9 , 10. Sample 425-5-4, 74-76 cm (68 m).

Figures 11, 12 Octactis pulchra Schiller.

11. Sample 425-1-2, $110-112 \mathrm{~cm} \mathrm{(3} \mathrm{m).}$

12. Sample 427-3-2, 70-72 cm (15 m).

Figures 13-16 Dictyocha spp.

Unique variants.

13. Sample 425-3-5, 74-76 cm (31 m).

14. Sample $425-3-3,74-76 \mathrm{~cm}(28 \mathrm{~m})$.

15. Sample $425-5-1,74-76 \mathrm{~cm}(63 \mathrm{~m})$.

16. Sample $428-4-3,74-76 \mathrm{~cm}(52 \mathrm{~m})$. 
PLATE 8
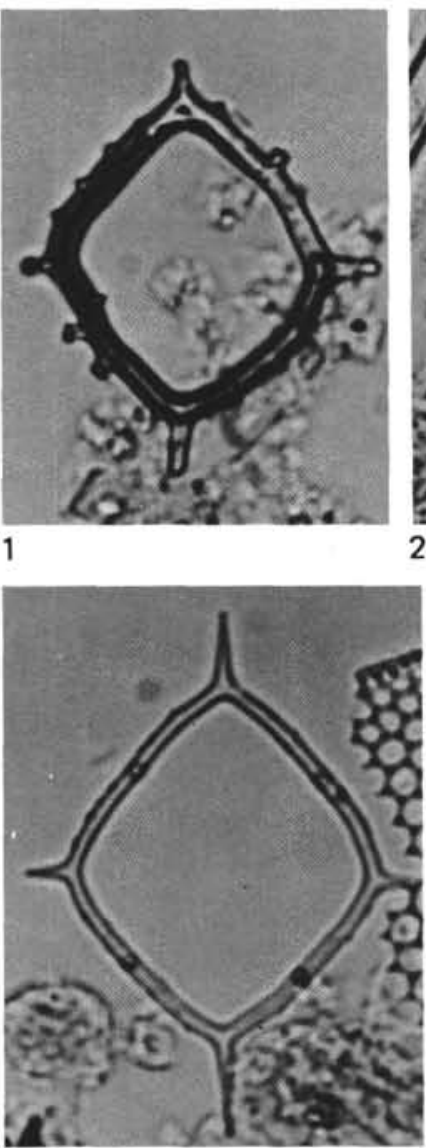

5

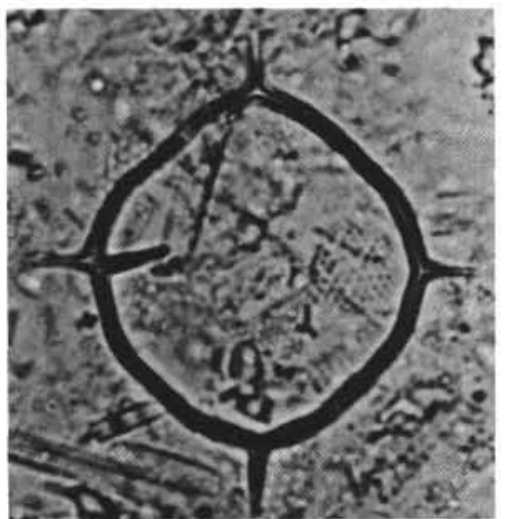

9

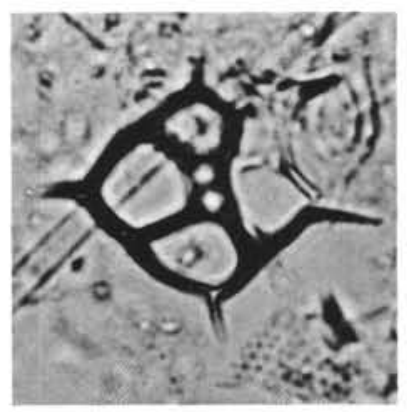

13

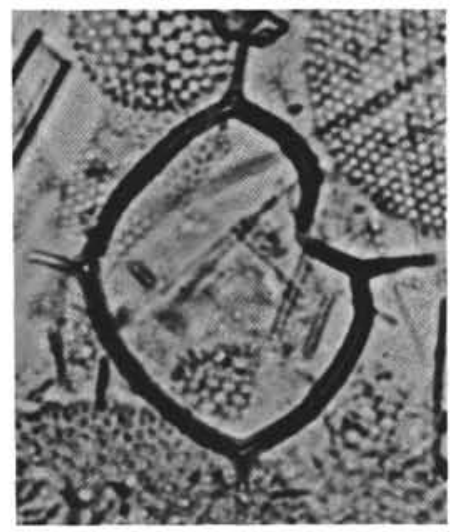

2

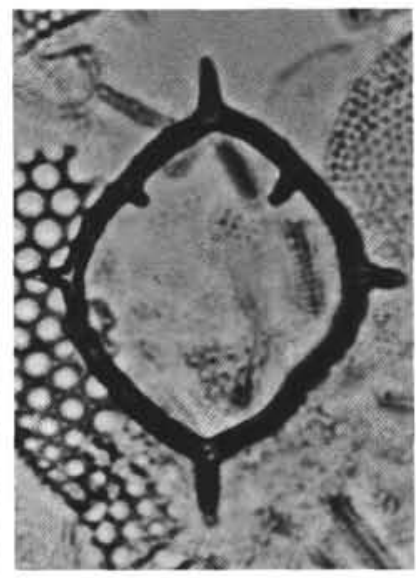

6
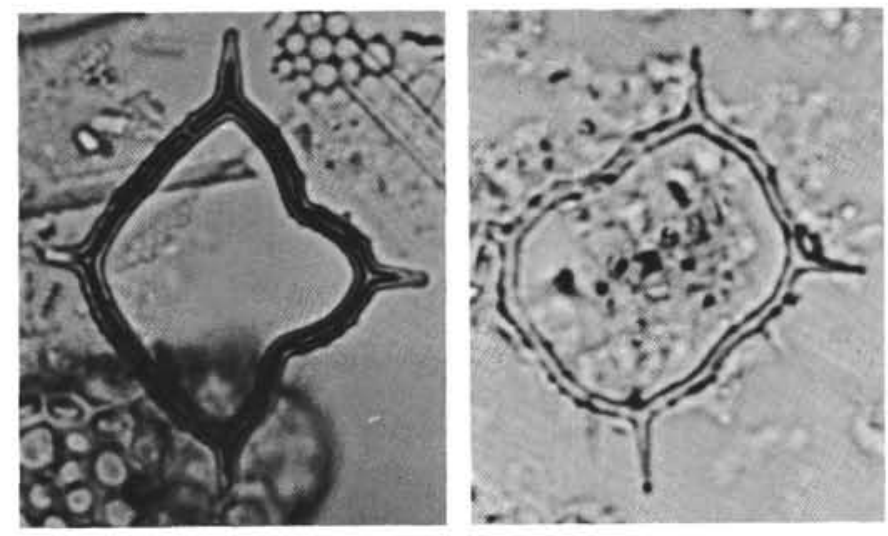

3

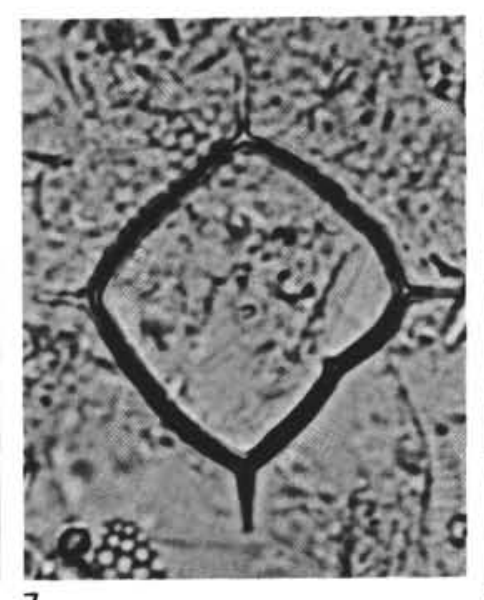

7
4

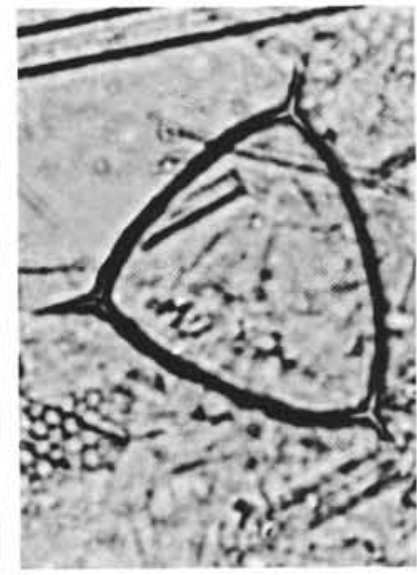

8

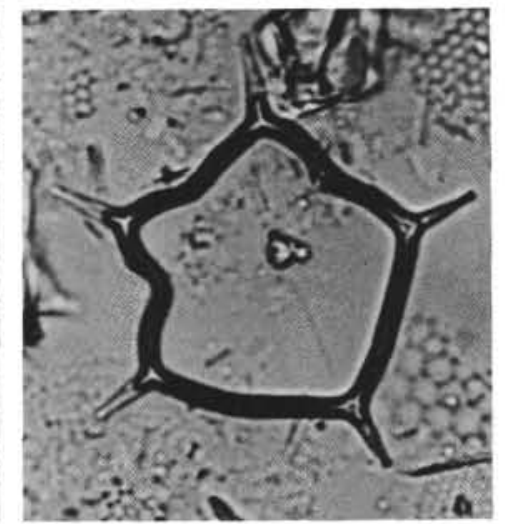

10

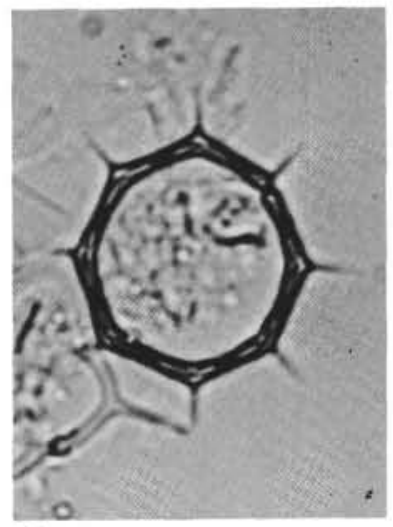

11

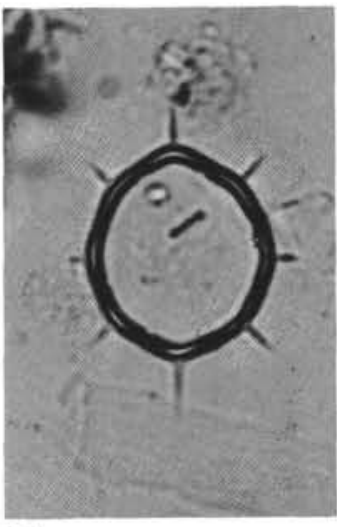

12

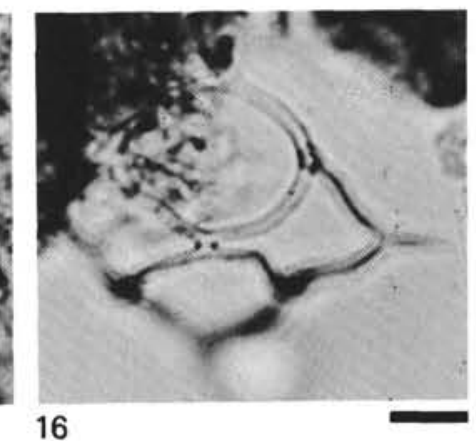




\section{PLATE 9}

Silicoflagellates (Figures 1, 2), Diatoms (Figures 3-6). Sponge

Spicules (Figures 7-10), and Opal Phytoliths (Figures 11-14)

$$
\text { from DSDP Leg } 54 .
$$

Figures 1, 2, 4-14 magnified $\times 800$; scale bar equals $10 \mu \mathrm{m}$.

Figure 3 magnified $\times 350$; scale bar equals $20 \mu \mathrm{m}$.

Figures 1, 2 Dictyocha sp.

Variant from Ceratolithus cristatus Subzone of the Galapagos sites; scarce.

1. Sample 425-2-3, 74-76 cm (9 m).

2. Sample 424B-2-3, 120-122 cm (8 m).

Figures 3, 4 Thalassiosira leptopus elliptica (Kolbe).

3. Sample 428-2-3, 74-76 cm (33 m).

4. Sample 425-4-1, 74-76 cm (44 m).

Figure 5 Coscinodiscus reniformis Castracane. Sample 425-4-2, 74-76 cm (46 m).

Figure $6 \quad$ Liostephania sp.

Remnant Asteromphalus areolation. Sample 4256-1, 74-76 cm (73 m).

Figures 7, 8 Oxea, curved.

Widely distributed in Leg 54 and deep-sea sediment.

7. Sample 427-7-3, 74-76 cm (93 m).

8. Sample $425-2-3,74-76 \mathrm{~cm}(9 \mathrm{~m})$

Figure 9 Microsclere or small radiolarian spicule?

Widely distributed in Leg 54 lower Quaternary. Sample 427-7-3, 74-76 cm (93 m).

Figure $10 \quad$ Spiraster.

Sample 425-2-3, 74-76 cm (9 m).

Figures 11-14 Panicoid opal phytoliths.

11. Sample 428-3-1, 74-76 cm (39 m).

12. Sample 420-11-2, 124-126 cm (92 m).

13. Sample $428-4-3,74-76 \mathrm{~cm}(52 \mathrm{~m})$.

14. Pancoid arrangement within a grass sliver, Sample 428-4-5, 74-76 cm (55 m). 
PLATE 9
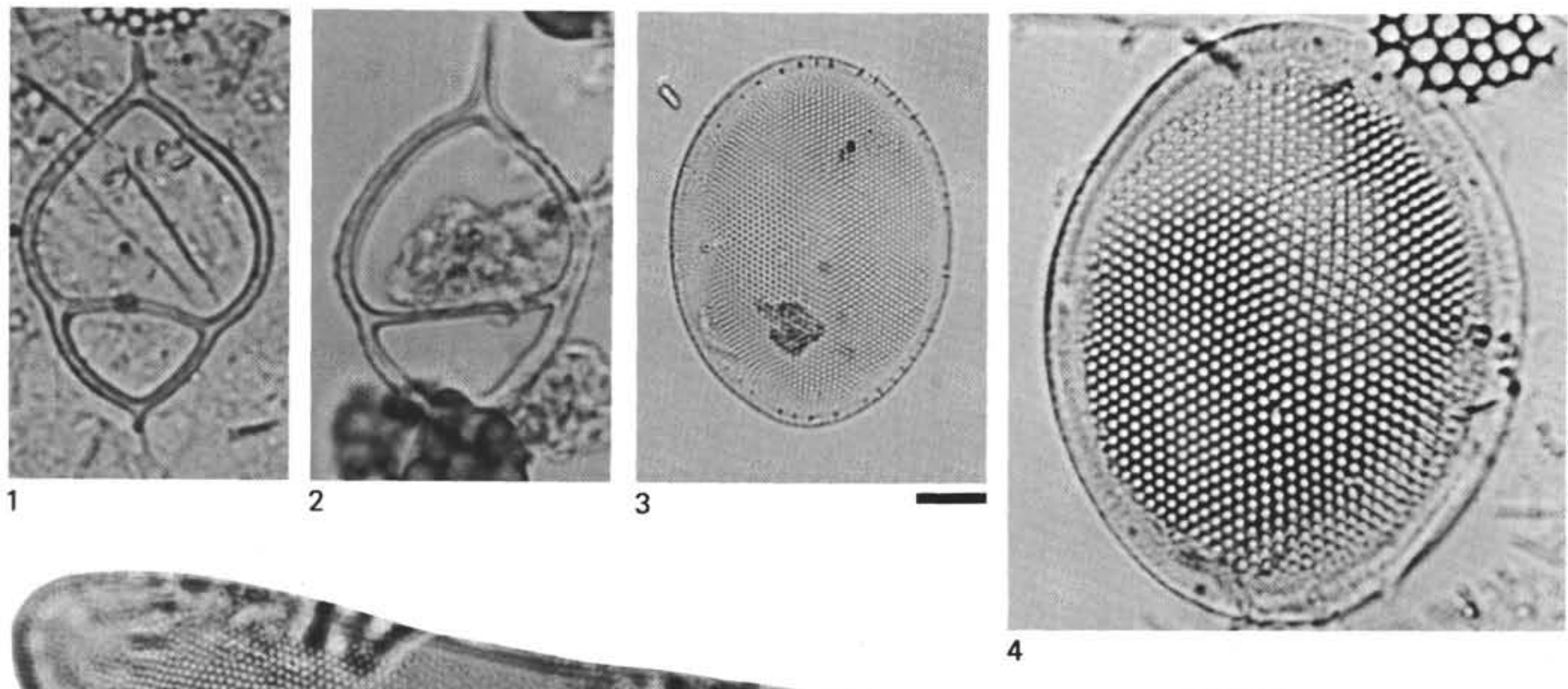

4
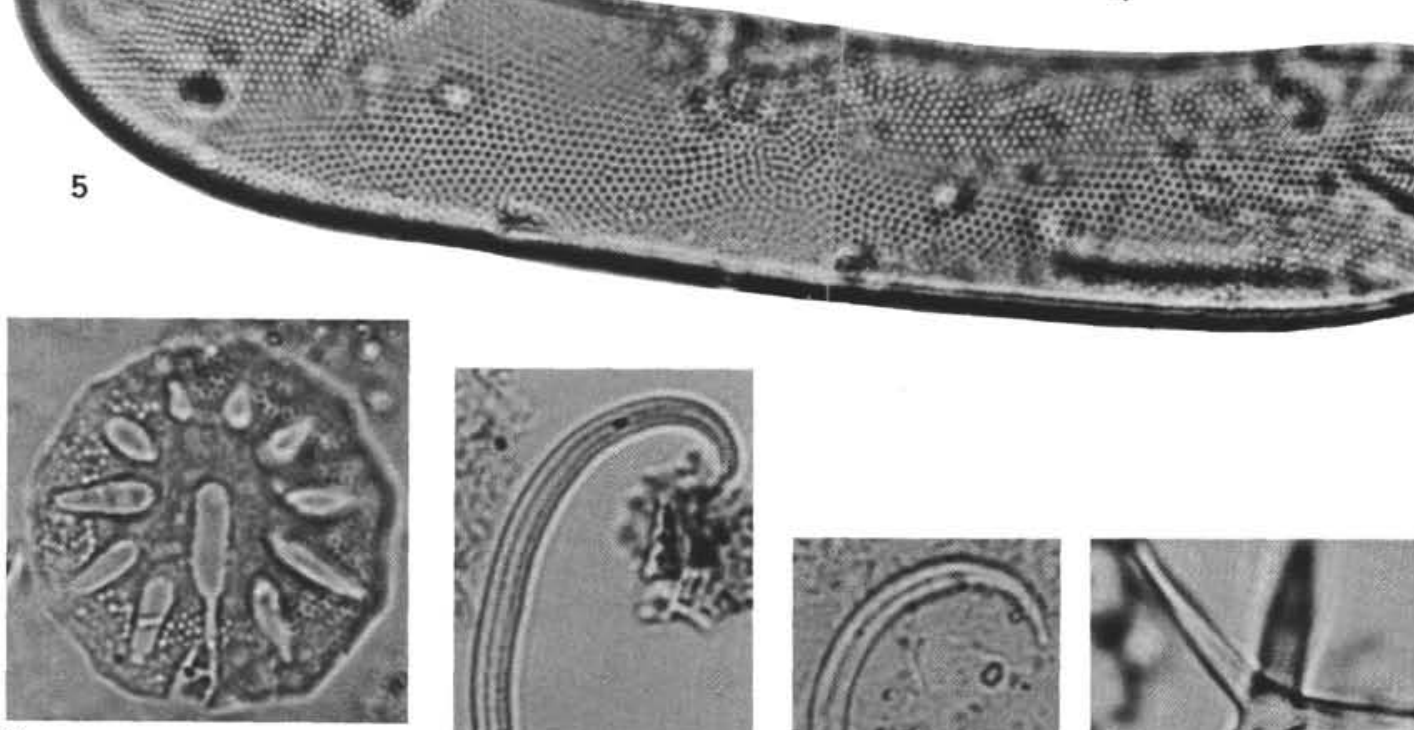

6
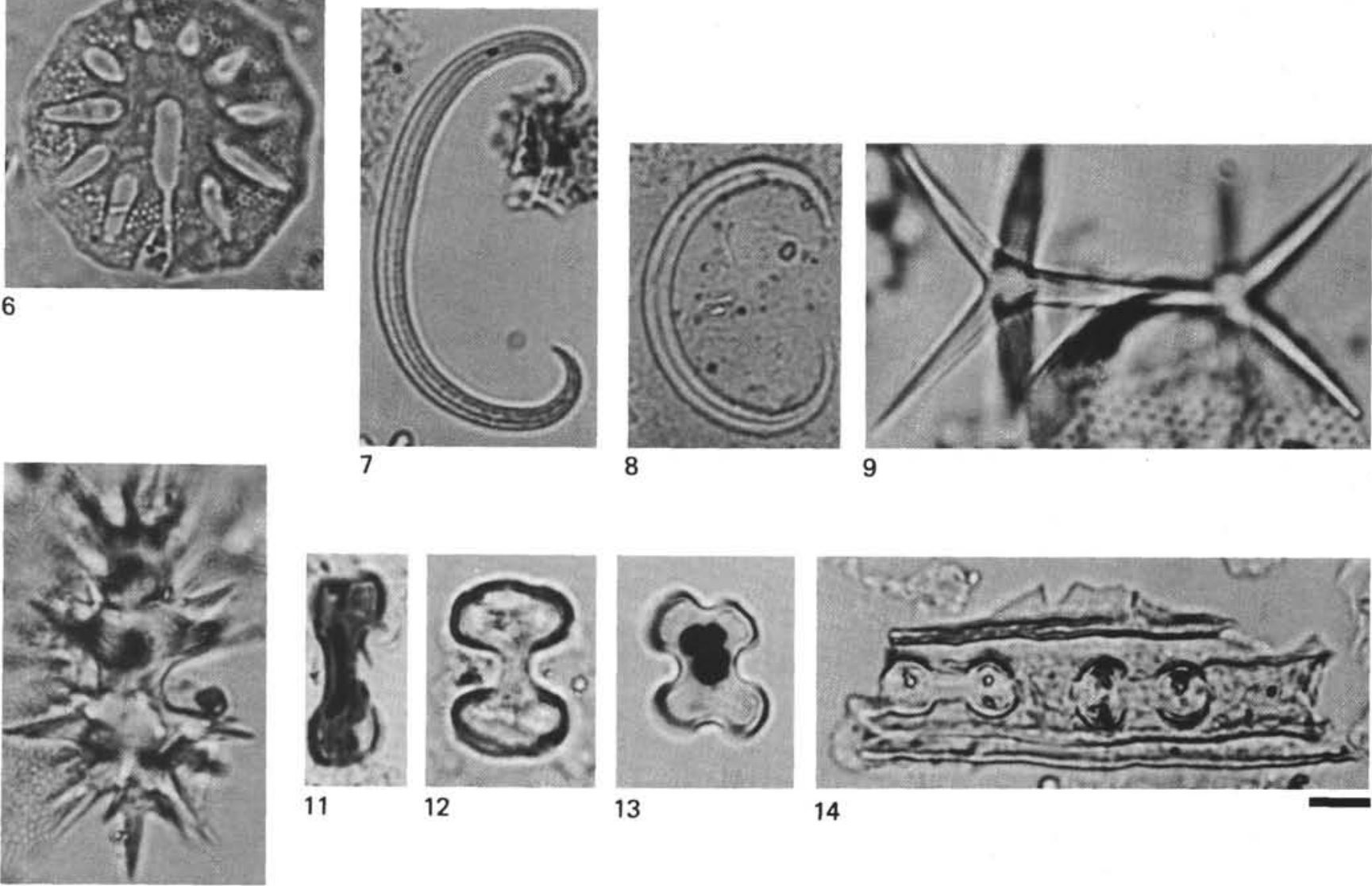

8

9
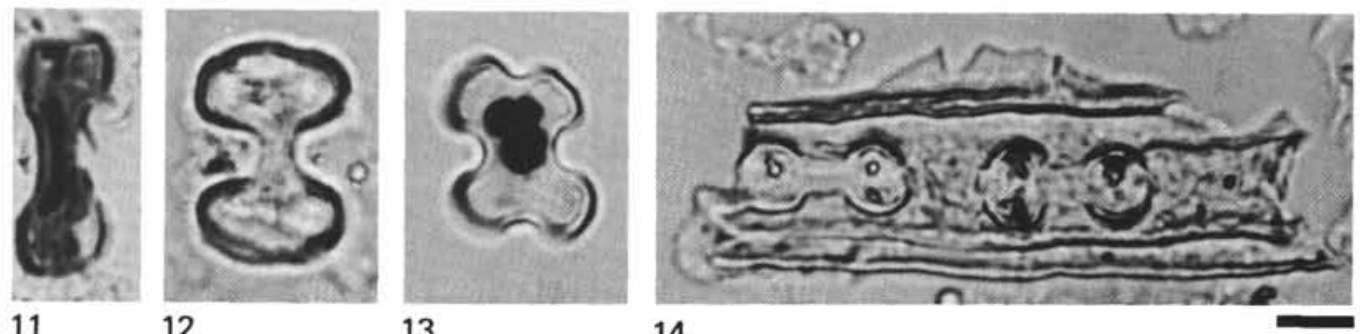